This is an Accepted Manuscript of an article published by IOP Publishing.

Journal of Breath Research, 2017, vol. 11, no. 4, article number 047102. The final publication is available at IOPSciencevia https://doi.org/10.1088/1752-7163/aa7cc0.

\title{
Comparison of feasibility and estimates of central and peripheral nitric oxide parameters by different mathematical models Tuomas Karvonen ${ }^{1}$, Hannu Kankaanranta ${ }^{1,3}$, Seppo Saarelainen ${ }^{2}$, Eeva Moilanen ${ }^{1}$ and Lauri Lehtimäki ${ }^{1,4}$
}

${ }^{1}$ Faculty of Medicine and Life Sciences, University of Tampere, Tampere, Finland

${ }^{2}$ Department of Respiratory M edicine, Tampere University Hospital, Tampere, Finland

${ }^{3}$ Department of Respiratory M edicine, Seinäjoki Central Hospital, Seinäjoki, Finland

${ }^{4}$ Allergy Centre, Tampere University Hospital, Tampere, Finland

Email: lauri.lehtimaki@uta.fi

Keywords: nitric oxide, breath tests, mathematical model, asbestos, COPD, healthy volunteers 


\section{ABSTRACT}

Introduction: Assessing central and peripheral nitric oxide (NO) dynamics of the lung provides information on the severity and anatomical site of pulmonary inflammation. Several mathematical methods to calculate alveolar and bronchial NO parameters have been introduced. Our aim was to compare these methods.

Methods: The study included 69 healthy adults, 66 healthy children, 73 asbestos-exposed subjects and 72 subjects with chronic obstructive pulmonary disease (COPD). Exhaled NO was measured at multiple flow rates and we used five mathematical methods (Tsoukias \& George, Pietropaoli, Condorelli, Högman \& M eriläinen, and Silkoff) to estimate alveolar and bronchial NO parameters.

Results: $H \& M$ method was less frequently feasible compared to other methods but it had the highest degree of agreement with the measured data. The methods were most often feasible in healthy or asbestos-exposed adults but distinctly more infrequently in children and adults with COPD, suggesting difficulties in NO measurements in these groups. The linear methods (T\&G, Pietropaoli) yielded higher alveolar NO concentration and lower bronchial NO flux than the two non-linear methods (H\&M, Silkoff) and linear method with correction for axial back-diffusion of NO (Condorelli).

Conclusion: In differentiating central and peripheral NO sources we recommend using the linear methods, as low flow rates are not needed and the feasibility of the methods is good. If bronchial wall NO concentration $\left(\mathrm{C}_{\mathrm{aw}} \mathrm{NO}\right)$ and diffusing capacity $\left(\mathrm{D}_{\mathrm{aw}} \mathrm{NO}\right)$ are of interest, non-linear methods are needed and we recommend using H\&M method as only three flow rates are needed. However, the agreement between the model and measured data needs to be checked in real-time to ensure feasibility. If the subject has difficulties with the extremely low or high flow rates, we then recommend using the Silkoff method to improve feasibility, but more flow rates and measurements are then needed and the agreement between the model and the measured data may be poorer. 


\section{Introduction}

M easurement of exhaled $\mathrm{NO}$ concentration $\left(\mathrm{F}_{\mathrm{E}} \mathrm{NO}\right)$ is a promising tool to determine inflammation in different lung diseases. Currently, we have the best knowledge of asthma. In particular groups, $\mathrm{F}_{\mathrm{E}} \mathrm{NO}$ can be used to predict treatment responsiveness. For instance, a high $\mathrm{F}_{\mathrm{E}} \mathrm{NO}$ in asthma has been found to predict a good response to inhaled corticosteroids [1-3]. However, using more than one flow rate in NO measurement permits calculating bronchial and alveolar NO independently. This provides more information on the site of inflammation.

\subsection{The Two-compartment model}

Nikolaos M. Tsoukias and Steven C. George described the NO exchange dynamics of the lungs by the twocompartment model in 1998 [4]. In the two-compartment model, lungs are divided into two regions: expansible alveolar and rigid bronchial regions (Figure 1). Alveolar and bronchial regions are different in gas exchange perspective, enabling to calculate the origin of NO using the two-compartment model. The twocompartment model is capable of explain three experimentally observed features of the NO exchange dynamics: 1) holding breath prior to NO measurement creates a peak in $F_{E} N O, 2$ ) $F_{E} N O$ is inversely proportional to flow rate, 3) NO elimination rate $\left(\mathrm{V}_{\mathrm{NO}}\right)$ from the lungs is directly proportional to flow rate [5]. 


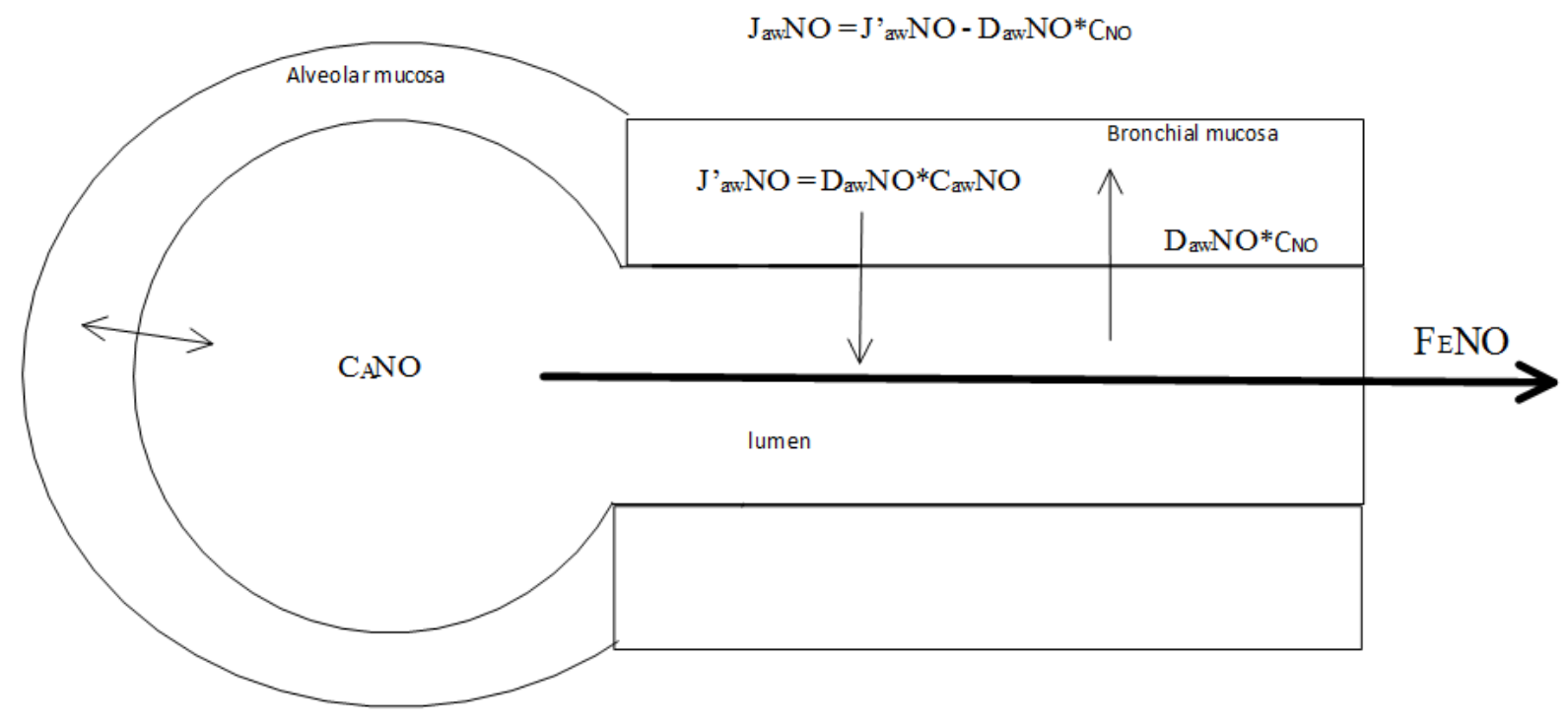

Alveolar region

Conducting airways

Figure 1. Drawing of the two-compartment model. Exhaled NO concentration $\left(\mathrm{F}_{\mathrm{E}} \mathrm{NO}\right)$ is the sum of alveolar and bronchial contributions. The bronchial or airway region's contribution depends on three flow-independent variables: maximum $\mathrm{NO}$ flux from the bronchial wall $\left(\mathrm{J}^{\prime}{ }_{\text {aw }} \mathrm{NO}, \mathrm{pl} / \mathrm{s}\right)$, $\mathrm{NO}$ concentration of bronchial mucosa $\left(\mathrm{C}_{\mathrm{aw}} \mathrm{NO}, \mathrm{ppb}\right)$ and diffusing capacity of $\mathrm{NO}$ from the bronchial wall $\left(\mathrm{D}_{\mathrm{aw}} \mathrm{NO}, \mathrm{pl} / \mathrm{s} / \mathrm{ppb}\right)$. Alveolar contribution depends on steady state alveolar $\mathrm{NO}$ concentration $\left(\mathrm{C}_{\mathrm{A}} \mathrm{NO}, \mathrm{ppb}\right)$.

\subsection{The Trumpet model with axial back-diffusion (TMAD)}

The two-compartment model assumes the conducting airways as an even, cylinder shaped tube, neglecting the fact that the bronchial tree branches towards the more distal airways. Condorelli et al. introduced the trumpet model of the lungs with correction for axial back-diffusion of NO (TMAD), where the conducting airways are considered as trumpet shaped [6]. This takes account the increasing total cross-sectional area and the mucosal surface area of the airways as the bronchial tree branches into smaller bronchioles. As the total cross-sectional area of the airways increases, the velocity of airflow decreases, especially in the last generations of the bronchial tree. The significant decrease in airflow velocity allows axial back-diffusion of NO from the higher NO concentration of the conducting region into the respiratory region, according to the NO concentration gradient. It has been proposed that neglecting this axial back-diffusion of NO leads to over estimation of $\mathrm{C}_{\mathrm{A}} \mathrm{NO}$ and under estimation of $\mathrm{J}_{\text {aw }} \mathrm{NO}$. However, this model is recommended to be utilized only in subjects with no obstruction or it can lead to overcorrection $[7,8]$. Some studies have also reported that the TM AD-correction leads to negative $\mathrm{C}_{\mathrm{A}} \mathrm{NO}$ values [9-11]. 


\subsection{The flow-independent NO parameters}

The two-compartment model describes alveolar and bronchial regions' NO exchange dynamics by flowindependent NO parameters: $\mathrm{C}_{\mathrm{ANO}}$ (steady state $\mathrm{NO}$ concentration in the alveolar region) describing the alveolar region, $\mathrm{C}_{\mathrm{aw}} \mathrm{NO}$ ( $\mathrm{NO}$ concentration in bronchial mucosa) and $\mathrm{D}_{\mathrm{aw}} \mathrm{NO}$ (NO diffusing capacity of the bronchial wall) representing the bronchial region. Maximal bronchial $\mathrm{NO}$ flux can be calculated as J ${ }^{\prime}$ aw $\mathrm{NO}=$ $\mathrm{D}_{\mathrm{aw}} \mathrm{NO} * \mathrm{C}_{\mathrm{aww}} \mathrm{NO}$ and bronchial $\mathrm{NO}$ flux as $\mathrm{aww}_{\mathrm{aw}} \mathrm{NO}=\mathrm{D}_{\mathrm{aw}} \mathrm{NO}\left(\mathrm{C}_{\mathrm{aw}} \mathrm{NO}-\mathrm{C}_{\mathrm{A}} \mathrm{NO}\right)$. Once flow-independent parameters are determined, the two-compartment model can be used to predict exhaled NO concentration ( $p p b$ ) in certain exhalation flow rate $\left(V_{\mathrm{E}}\right)$ by exponential function

$\mathrm{F}_{\mathrm{E}} \mathrm{NO}=\mathrm{C}_{\mathrm{aw}} \mathrm{NO}+\left(\mathrm{C}_{\mathrm{A}} \mathrm{NO}-\mathrm{C}_{\mathrm{aw}} \mathrm{NO}\right) * \exp \left(-\mathrm{D}_{\mathrm{aw}} \mathrm{NO} / \mathrm{V}_{\mathrm{E}}\right)[4,5,12,13]$

When $V_{E}$ is large compared to $D_{a w} N O\left(V_{E}>\sim 5 * D_{a w} N O\right)$, the exponential function approaches its first-order linear approximation ( $\left.\exp \left(-\mathrm{D}_{\mathrm{aw}} \mathrm{NO} / \mathrm{Ve}\right)=1-\mathrm{D}_{\mathrm{aw}} \mathrm{NO} / \mathrm{V}_{\mathrm{E}}\right)[5]$. When this approximation is used in equation 1 , the equation reduces to following

$\mathrm{F}_{\mathrm{E}} \mathrm{NO}=\mathrm{C}_{\mathrm{A}} \mathrm{NO}+\left(\mathrm{C}_{\mathrm{aw}} \mathrm{NO}-\mathrm{C}_{\mathrm{A}} \mathrm{NO}\right) \mathrm{D}_{\mathrm{aw}} \mathrm{NO} * \frac{1}{\mathrm{VE}}$

Knowing the fact that $]_{a w} \mathrm{NO}=\mathrm{D}_{\mathrm{aw}} \mathrm{NO}\left(\mathrm{C}_{\mathrm{aw}} \mathrm{NO}-\mathrm{C}_{\mathrm{A}} \mathrm{NO}\right)$, equation 2 can be reduced to

$\mathrm{F}_{\mathrm{E}} \mathrm{NO}=\mathrm{C}_{\mathrm{A}} \mathrm{NO}+\mathrm{J}_{\mathrm{aw}} \mathrm{NO} * \frac{1}{\mathrm{VE}}$

When both sides of this equation 3 are multiplied by $\mathrm{V}_{\mathrm{E}}$, linear equation of $\mathrm{NO}$ elimination rate is derived

$\mathrm{V}_{\mathrm{NO}}=\mathrm{C}_{\mathrm{A}} \mathrm{NO} * \mathrm{Ve}+\mathrm{J}_{\mathrm{aw}} \mathrm{NO}$

\subsection{Analytical methods}

There are several techniques to approximate the flow-independent NO parameters based on measurements of $\mathrm{F}_{\mathrm{ENO}}$ at multiple flow rates. In this study, we used four different methods which will be introduced herein. Tsoukias et al. [14] used linear equation 4 above in assessing $\mathrm{C}_{\mathrm{A}} \mathrm{NO}$ and $\mathrm{J}_{\text {aw }} \mathrm{NO}$ (Figure 2A). In this method, $\mathrm{F}_{\mathrm{E}} \mathrm{NO}$ is measured at several high ( $\geq 100 \mathrm{ml} / \mathrm{s}$ to verify that $V_{E}>\sim 5^{*} D_{a w} N O$ ) flow rates. $V_{N O}$ is calculated from measured $F_{E} N O$ and the flow rates used. Then $V_{N O}$ is plotted against flow rate $V_{E}$ and a regression line is set between $V_{N O}$ and $V_{E} . C_{A} N O$ is obtained from the slope and $J_{a w} N O$ from the intercept of the regression line. 
Pietropaoli et al. [12] utilized linear equation 3 to estimate $\mathrm{C}_{\mathrm{A}} \mathrm{NO}$ and $\mathrm{J}_{\text {aw }} \mathrm{NO}$ (figure $2 \mathrm{~B}$ ). In this method, the measured value of $F_{E} N O$ at several high $\left(\geq 100 \mathrm{ml} / \mathrm{s}\right.$ ) flow rates are plotted against $\frac{1}{\mathrm{VE}}$ and a regression line is set between $\mathrm{F}_{\mathrm{E}} \mathrm{NO}$ and $\frac{1}{\mathrm{VE}}$. The intercept is used as an estimate for $\mathrm{C}_{\mathrm{A}} \mathrm{NO}$ whereas slope for $\mathrm{J}_{\text {aw }} \mathrm{NO}$.

Condorelli et al. used the Tsoukias \& George method to calculate $\mathrm{C}_{\mathrm{A}} \mathrm{NO}$ and $\mathrm{J}_{\mathrm{aw}} \mathrm{NO}$ with correction of the axial back-diffusion by applying correction factors $a$ and $b$ in the following equations [6]:

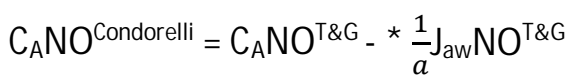

$\mathrm{J}_{\mathrm{aw}} \mathrm{N} \mathrm{O}^{\text {Condorelli }}=\mathrm{J}_{\mathrm{aw}} \mathrm{NO} \mathrm{O}^{\mathrm{T} \& \mathrm{G} * \mathrm{~b}}$

The values of correction factors $a$ and $b$ are dependent on flow rates used in measurements.

Silkoff et al. [15] utilized a nonlinear regression analysis using equation 1 to determine all three flowindependent parameters by measuring $\mathrm{F}_{\mathrm{E}} \mathrm{NO}$ at several high and low flows (figure $2 \mathrm{C}$ ). Högman et al. [13,16] used a method that combines some of the methods described above (figure 2D). Three flow rates are needed: one low, one medium and one high. $\mathrm{C}_{\mathrm{A}} \mathrm{NO}$ is estimated as in Tsoukias \& George method: a regression line is set between $V_{N O}$ and $V_{E}$ at medium and high flow rates, and the slope is used as an estimate of $C_{A} N O$. $D_{a w} N O$ is obtained using low and medium flow rates with an iterative technique, whereas $\mathrm{C}_{\text {aw }} \mathrm{NO}$ is estimated using $\mathrm{D}_{\mathrm{aw}} \mathrm{NO}$ and $\mathrm{C}_{\mathrm{A}} \mathrm{NO}$ obtained earlier. 


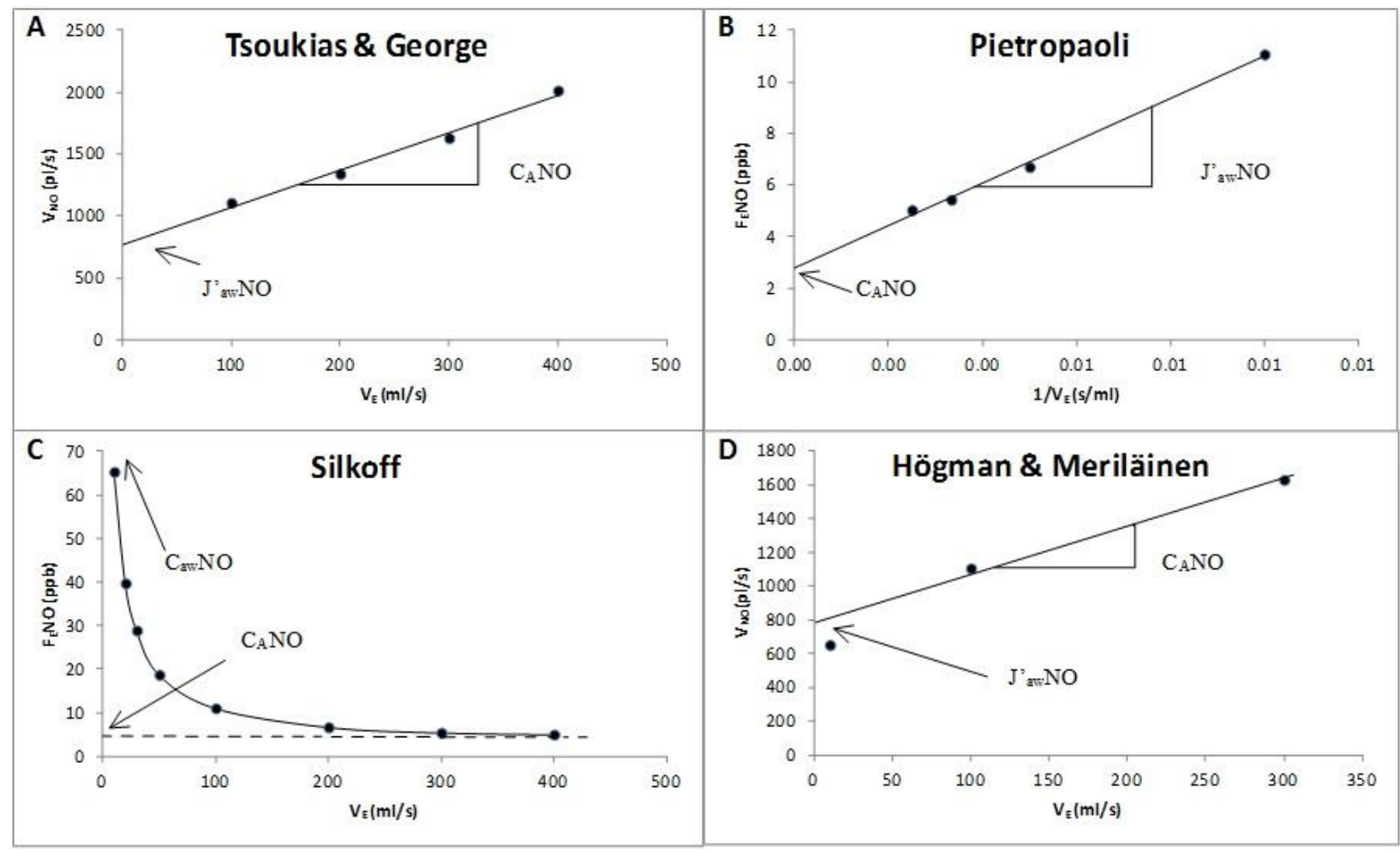

Figure 2. Schematics describing the mathematical methods used. Tsoukias $\&$ George $A: V_{N O}$ is plotted against flow rate $V_{E}$ and a regression line is set between $V_{N O}$ and $V_{E} . C_{A} N O$ is obtained from the slope and $J_{a w} N O$ from the intercept of the regression line. In Condorelli method, parameters are calculated likewise before applying the flow rate dependent correction factors. Pietropaoli $\mathrm{B}$ : $\mathrm{F}_{\mathrm{E}} \mathrm{NO}$ is plotted against $\frac{1}{\mathrm{VE}}$ and a regression line is set between $F_{E} N O$ and $\frac{1}{V E}$. The intercept is used as an estimate for $C_{A} N O$ whereas slope for $J_{a w} N O$. Silkoff $C_{\text {: }} F_{E} N O$ is plotted against $V_{E}$ using all measured flow rates. $C_{a w} N O$ is the intercept of the plot. $C_{A} N O$ is the limit of $F_{E} N O$ when $V_{E}$ approaches infinity $\left(F_{E} N O=C_{A} N O\right.$, when $\left.V_{E} \rightarrow \infty\right)$. $D_{a w} N O$ describes the steepness of the plot: small $\mathrm{D}_{\text {aw }} \mathrm{NO}$ makes the plot steeper. The parameters are calculated by fitting the governing equation (Equation 1 ) to the observed data by regression analysis. Högman \& Meriläinen D: $\mathrm{C}_{\mathrm{A}} \mathrm{NO}$ and $\mathrm{J}_{\mathrm{aw}} \mathrm{NO}$ are obtained by using high and medium flow rates as in Tsoukias $\&$ George method. $\mathrm{D}_{\text {aw }} \mathrm{NO}$ is then calculated using $\mathrm{J}_{\text {aw }} \mathrm{NO}$ and $\mathrm{F}_{\mathrm{E}} \mathrm{NO}$ at low and medium flow rates using an iterative technique. $\mathrm{C}_{\text {aw }} \mathrm{NO}$ is then calculated by using all previously calculated parameters.

\subsection{Aims of the study}

It is important to know whether there are significant differences between the existing methods in NO parameter estimation. Sometimes the original measurement data does not fit the mathematical equation used to estimate the flow-independent NO parameters and the iterative process does not converge or impossible results are obtained (i.e. the method is not feasible in that subject). There may also be differences in the model's degree of agreement with the measured data (i.e. what is the difference between measured $\mathrm{F}_{\mathrm{E}} \mathrm{NO}$ and calculated $\mathrm{F}_{\mathrm{E}} \mathrm{NO}$ ). Also, the magnitudes of calculated NO parameters may differ between methods and used flow rates. In spite of importance in the development of the methods, comparative studies are scarce. 
The aim of the present study was to compare different analytical methods (Tsoukias \& George (T\&G), Pietropaoli, Condorelli, Silkoff and Högman \& M eriläinen (H\&M)) to calculate NO parameters regarding 1) their feasibility (how often the mathematical analysis succeeded and provided results that were not considered as outliers or physically impossible), 2) their degree of agreement with measured data (difference between calculated and observed $\mathrm{F}_{\mathrm{E}} \mathrm{NO}$ value), 3) the magnitude of calculated NO parameters and 4) the effect of the used flow rates on the feasibility and calculated NO parameters.

\section{Methods}

\subsection{Subjects}

In the analysis, we included subjects from several of our previously published studies utilizing $\mathrm{F}_{\mathrm{E}} \mathrm{NO}$ measurements at multiple flow rates. The groups were 69 healthy adults, 66 healthy children, 72 adults with COPD and 73 adult subjects with previous asbestos exposure. The inclusion and exclusion criteria and clinical characteristics are previously published [17-19]. In short, subjects with COPD were newly diagnosed with no current anti-inflammatory treatment. They had symptoms compatible with COPD, post-bronchodilator FEV1/forced vital capacity (FVC) ratio <0.7, smoking history of at least 20 pack-years, and emphysema on highresolution computed tomography (HRCT) of the lungs. The subjects with previous asbestos exposure were nonsmoking males with a history of moderate to severe occupational exposure to asbestos without other known respiratory diseases.

As the sample size in the current study is predetermined by the original studies, we made a post hoc calculation of statistical power for the current analysis. We considered differences in NO parameters given by the 5 different calculation methods as main outcome. Using repeated measures ANOVA with $\alpha$-error of $5 \%$, a sample size of 31 subjects is needed to get statistical power of $95 \%$ to detect a difference between the methods that is 0.25 times standard deviation (to keep the estimate conservative we estimated correlation among repeated measures to be 0.5 and used correction for nonsphericity as 1 , G*Power 3.1.7 was used in calculations). As nonparametric tests are usually more conservative that parametric tests and as we used nonparametric Friedman's test instead of parametric ANOVA in comparisons, we consider that we have sufficient statistical power in each comparison where the number of subjects with successful measurements is above forty. 


\subsection{NO measurement}

As previously described [17-19], exhaled NO was measured using Sievers NOA 280 chemiluminescent analyzer (Sievers Instruments, Boulder, Colorado, USA) at different flow rates. We outlaid the flow rates of 10, 50, 100, 200 and $300 \mathrm{ml} / \mathrm{s}$ for the healthy children, whereas flow rates of 10,20,30,50,100,200, 300 and $400 \mathrm{ml} / \mathrm{s}$ were used for the adult subjects. At least two successful NO measurements with coefficient of variation (CV) of maximum $3 \%$ were performed at each flow rate. The desired flow rates were achieved by letting the subjects exhale through a mass flow meter connected to a computer-controlled, adjustable flow restrictor that kept the flow rate steady at the desired level. The linearity of $V_{N o}$ at flows $\geq 100 \mathrm{ml} / \mathrm{s}$ was evaluated later in the analysis phase and $r<0.95$ was used as an exclusion criterion in the linear methods.

\subsection{Calculation of NO parameters}

Before performing any calculations, we visually inspected every $\mathrm{F}_{\mathrm{E}} \mathrm{NO}$ versus flow rate plot. Plots were accommodated by omitting failed measurements (i.e. if $\mathrm{F}_{\mathrm{E}} \mathrm{NO}$ at $300 \mathrm{ml} / \mathrm{s}<\mathrm{F}_{\mathrm{E}} \mathrm{NO}$ at $400 \mathrm{ml} / \mathrm{s}$, flow rate of 400 $\mathrm{ml} / \mathrm{s}$ can be discarded as failed measurement) and using nearest successful measurement point if possible. In healthy adults, the flow rate of $400 \mathrm{ml} / \mathrm{s}$ was excluded 14 times and at least one of the flow rates between 10 and $30 \mathrm{ml} / \mathrm{s}$ were excluded 4 times. The corresponding numbers for previous asbestos exposure group were 9 and 3 and in the group of COPD patients 13 and 4 . Only $2300 \mathrm{ml} / \mathrm{s}$ flow rates were excluded in healthy children. If the plot was beyond accommodation, the subject was excluded from the analysis. A total of 15 plots were beyond accommodation in COPD patients and 2 in healthy children in linear methods (these were considered as visual drop-outs). The failed flow rates were almost exclusively $300 \mathrm{ml} / \mathrm{s}$ and $400 \mathrm{ml} / \mathrm{s}$. Five different analytical methods were used (T\&G, Pietropaoli, Condorelli, Silkoff and $H \& M$ ) to calculate the NO parameters in every subject group (Figure 2). All calculations were performed by using M icrosoft Excel 2007.

\subsubsection{Linear methods}

In T\&G method, $V_{N o}$ was plotted against $V_{E}$ and we used Excel functions "slope" and "intercept" to calculate $\mathrm{C}_{\mathrm{A}} \mathrm{NO}$ and $\mathrm{J}_{\mathrm{aw}} \mathrm{NO}$, respectively. Exhalation flow rates of 100, 200, 300 and $400 \mathrm{ml} / \mathrm{s}$ were used for adults, whereas 100, 200, $300 \mathrm{ml} / \mathrm{s}$ were used for children. Correlation coefficient between flow rate and $V_{\mathrm{No}}$ was calculated by using the correlation function in Excel. In Pietropaoli method, we used the same flow rates as in $T \& G$ method. $\mathrm{F}_{\mathrm{E}} \mathrm{NO}$ was plotted against $\frac{1}{\mathrm{VE}}$ and $\mathrm{C}_{\mathrm{A}} \mathrm{NO}$ was calculated using the intercept function and $\mathrm{J}_{\mathrm{aw}} \mathrm{NO}$ with the slope. The correlation coefficient between $\frac{1}{\mathrm{VE}}$ and $\mathrm{F}_{\mathrm{E}} \mathrm{NO}$ was also calculated. 
In Condorelli method, NO parameter estimates of the T\&G method were used. Correction for axial backdiffusion was then achieved by using the correction factors $(a=1100 \mathrm{ml} / \mathrm{s}, b=1.6$ with flow rates $100-400 \mathrm{ml} / \mathrm{s}$ and $a=840 \mathrm{ml} / \mathrm{s}, \mathrm{b}=1.7$ with flow rates $100-300 \mathrm{ml} / \mathrm{s}$ ) as introduced earlier (Equations 5 and 6). Failed measurements were excluded from the calculations as previously described. In adult subjects, one failed flow rate was allowed to be excluded. In the case of more than one failed flow rate, we excluded the subject.

\subsubsection{Non-linear methods}

In H\&M method, we used an Excel calculation sheet made by Pekka Meriläinen, one of the inventors of the method. We compared the results using different three flow rate combinations. The best combination of flow rates was found to be 10, 100 and $300 \mathrm{ml} / \mathrm{s}$ as it yielded relevant results with least outliers. Failed measurements were optimized by using the nearest possible flow rate in place of a failed one (e.g. replacing a failed $10 \mathrm{ml} / \mathrm{s}$ by $20 \mathrm{ml} / \mathrm{s}$ or failed $400 \mathrm{ml} / \mathrm{s}$ by $300 \mathrm{ml} / \mathrm{s}$ ).

In Silkoff method we compared Solver tool in Microsoft Excel 2007 and a commercial regression analysis software NLREG (nlreg.com). However, as both were found to function equally well in our purpose, we chose the Excel Solver to be used in the analysis. The Silkoff method is based on non-linear regression analysis in which observational data are modeled by a non-linear function. The calculated plot is attempted to fit the observational data by changing the model's parameters. We performed the non-linear regression analysis by using the least squares algorithm. The sums of the squared residuals of the observed and calculated $\mathrm{F}_{\mathrm{E}} \mathrm{NO}$ values at different flow rates are minimized by changing the model's parameters ( $D_{a w} N O, C_{a w} N O$ and $\left.C_{A} N O\right)$.

This method requires initial starting value for the iteration process. We used the medians of the $\mathrm{C}_{\mathrm{A}} \mathrm{NO}, \mathrm{C}_{\mathrm{aw}} \mathrm{NO}$ and $D_{a w} N O$ calculated for healthy adults using the $H \& M$ method as an initial starting value. After the iterations, the calculated parameter values were set as the new starting values for a new iteration process. The iteration cycle was repeated three more times, setting each time the previously obtained parameter values as new starting values. The number of iterations within each cycle depended on how quickly the Excel Solver converged to a solution with all constrains satisfied (precision $=0.000001$, tolerance $5 \%$ and convergence 0.0001). We used all available successful flow rates in calculations.

\subsection{Analysis}

\subsubsection{Checking the feasibility and excluding outliers}

After the calculation of the NO parameters with each of the methods, we evaluated the methods' feasibility in parameter estimation and excluded the outliers using the following criteria $\mathrm{C}_{\mathrm{A}} \mathrm{NO}<0, \mathrm{C}_{\mathrm{A}} \mathrm{NO}>10, \mathrm{C}_{\mathrm{aw}} \mathrm{NO}<0$ or $\mathrm{C}_{\mathrm{aw}} \mathrm{NO}>1000$. The upper limits were set according to previous results $[15,17,20-23]$ and histograms and lower 
limits are based on the fact that negative concentrations are not physically possible. Defining outlier criteria for $\mathrm{D}_{\mathrm{aw}} \mathrm{NO}$ was not considered necessary as excluding abnormal $\mathrm{C}_{\mathrm{A}} \mathrm{NO}$ and $\mathrm{C}_{\text {aw }} \mathrm{NO}$ values excluded abnormal $\mathrm{D}_{\text {aw }} \mathrm{NO}$ and $\mathrm{J}_{\text {aw }} \mathrm{NO}$ values as well at the same. This is explained by the fact that $\mathrm{C}_{\mathrm{aw}} \mathrm{NO}$ and $\mathrm{D}_{\mathrm{aw}} \mathrm{NO}$ are mathematically coupled and in cases of extremely low CawNO, DawNO is extremely high, and vice versa. In the linear methods, correlation coefficient less than 0.95 was also used as an exclusion criterion. In H\&M method there is an internal validity check also included. Negative, or otherwise impossible results as well as inferior correlation may conclude that the model of NO production of the respiratory system may be inadequate. It may also be due to problems in the measurement situation. A Cochran's Q test was used to assess if the proportion of feasibility differed significantly between the methods. If the p-value with Cochran's Q test was $<0.05$, pairwise comparison was performed to check which methods differed significantly from one another. IBM SPSS Statistics 24 was used in the statistical analysis.

\subsubsection{Checking the method's degree of agreement.}

We evaluated the methods' degree of agreement with the observational data by calculating absolute values of the difference between observed and calculated values of $\mathrm{F}_{\mathrm{E}} \mathrm{NO}$. A flow rate of $100 \mathrm{ml} / \mathrm{s}$ was used in the comparison of the measured and calculated $\mathrm{F}_{\mathrm{E}} \mathrm{NO}$, since linear methods apply with higher flow rates only and this flow rate also did not produce difficulties for most of the subjects. The difference between the methods was compared using nonparametric Friedman's repeated two-way ANOVA.

\subsubsection{Comparing the magnitude of NO parameters between the methods.}

After calculating all the NO parameters with all the methods, the distributions of the calculated parameters were compared between different methods using nonparametric Friedman's repeated two-way ANOVA. The results are presented as median, inter-quartile range (IQR), minimum and maximum in the tables.

\subsubsection{The effect of the used flow rates on the feasibility and NO parameters.}

We also assessed the effect of used flow rates in parameter estimates. We calculated the NO parameters for healthy adults with all flow rates successful $(n=56)$ using two different methods, linear T\&G and non-linear $H \& M$. Flow rates of 100, 200 and $300 \mathrm{ml} / \mathrm{s} ; 200,300$ and $400 \mathrm{ml} / \mathrm{s}$; and 100,200, 300 and $400 \mathrm{ml} / \mathrm{s}$ were used in T\&G method, whereas flow rates of 10,100 and $400 \mathrm{ml} / \mathrm{s} ; 10,100$ and $300 \mathrm{ml} / \mathrm{s} ; 20,100$ and $400 \mathrm{ml} / \mathrm{s}$; and 20,100 and $300 \mathrm{ml} / \mathrm{s}$ were used in $\mathrm{H} \& M$ method, respectively. After calculating the parameters, outliers were 
excluded as previously described. The distributions of the calculated parameters were compared between different flow rates using nonparametric Friedman's repeated two-way ANOVA.

\section{Results}

Basic demographics of the subjects are introduced in the Table 1.

Table 1. Basic demographics of the subjects.

\begin{tabular}{ccccc}
\hline & Healthy adults & Healthy children & Asbestos exposure & COPD \\
\hline $\mathrm{N}$ & 69 & 66 & 73 & 72 \\
$\mathrm{Sex}$ & $61 / 8$ & $32 / 34$ & All males & $50 / 22$ \\
Age & $63(63.5 \pm 7.4)$ & $9(9.7 \pm 1.6)$ & $65(64.9 \pm 6.6)$ & $58(58.5 \pm 7.6)$ \\
Fev1 \% pred. & n.a. & n.a. & $89.0(88.3 \pm 14.0)$ & $52.0(53.8 \pm 14.81)$ \\
Sex is presented as (males / females) & & \\
Age and Fev1 \% pred. are presented as median (mean \pm SD) & & \\
\hline
\end{tabular}

\subsection{Feasibility of the methods}

The median correlation coefficients for linearity of $\mathrm{V}_{\mathrm{NO}}$ against flow at flow rates $\geq 100 \mathrm{ml} / \mathrm{s}$ were $>0.99$ in all groups, indicating a good linearity of measurements. We discovered significant differences in the feasibility of different methods between subject groups and between the methods (Table 2). Of the different subject groups, the feasibility of all methods was best in healthy adults and in adults with asbestos exposure. In healthy children, the feasibility was poorer and it was poorest in subjects with COPD.

When comparing the different methods in each subject group, linear methods tended to yield results slightly more often compared to the non-linear ones. In subject groups where the feasibility was lower (children and subjects with COPD), H\&M method was feasible significantly less frequently than the other methods. 
Table 2. Comparison of the feasibility of the mathematical methods in the parameter estimation and reasons for excluding outliers.

\begin{tabular}{|c|c|c|c|c|c|}
\hline & $\mathbf{T} \& \mathbf{G}$ & Pietropaoli & Condorelli & Silkoff & $H \& M$ \\
\hline \multicolumn{6}{|l|}{ Healthy Adults } \\
\hline Total number of subjects & 69 & 69 & 69 & 69 & 69 \\
\hline Visual estimation drop-out & 0 & 0 & 0 & 0 & 0 \\
\hline Outliers excluded, total & 6 & 2 & 8 & 8 & 11 \\
\hline$C_{A} N O<0$ & & & 2 & 4 & \\
\hline \multicolumn{6}{|l|}{$C_{A} N O>10$} \\
\hline$C_{a w} N O>1000$ & & & & 4 & 9 \\
\hline$r<0.95$ or H\&M validity check & 6 & 2 & 6 & & 2 \\
\hline Successful results & $63^{*}$ & 67 & 61 & 61 & 58 \\
\hline \multicolumn{6}{|l|}{ Healthy children } \\
\hline Total number of subjects & 66 & 66 & 66 & 66 & 66 \\
\hline Visual estimation drop-out & 2 & 2 & 2 & 1 & 1 \\
\hline Outliers excluded, total & 2 & 1 & 3 & 8 & 17 \\
\hline$C_{A} N O<0$ & & & 1 & 1 & \\
\hline \multicolumn{6}{|l|}{$C_{A} N O>10$} \\
\hline$C_{a w} N O>1000$ & & & & 7 & 16 \\
\hline$r<0.95$ or H\&M validity check & 2 & 1 & 2 & & 1 \\
\hline Successful results & $62^{\mathrm{H \& M}}$ & $63^{\mathrm{H \& M}}$ & $61^{\mathrm{H} \& \mathrm{M}}$ & $57^{\mathrm{HeM}}$ & 48 \\
\hline \multicolumn{6}{|l|}{ Asbestos exposure } \\
\hline Total number of subjects & 73 & 73 & 73 & 73 & 73 \\
\hline Visual estimation drop-out & 0 & 0 & 0 & 0 & 0 \\
\hline Outliers excluded, total & 2 & 0 & 3 & 4 & 7 \\
\hline$C_{A} N O<0$ & & & 1 & & \\
\hline \multicolumn{6}{|l|}{$C_{A} N O>10$} \\
\hline$C_{a w} N O>1000$ & & & & 4 & 7 \\
\hline$r<0.95$ or H\&M validity check & 2 & & 2 & & \\
\hline Successful results & $71^{* *}$ & 73 & 70 & 69 & 66 \\
\hline \multicolumn{6}{|l|}{ COPD } \\
\hline Total number of subjects & 72 & 72 & 72 & 72 & 72 \\
\hline Visual estimation drop-out & 15 & 15 & 15 & 0 & 0 \\
\hline Outliers excluded, total & 6 & 13 & 6 & 17 & 49 \\
\hline$C_{A} N O<0$ & & & 1 & 3 & \\
\hline$C_{A} N O>10$ & 4 & 3 & 3 & & \\
\hline$C_{a w} N O>1000$ & & & & 14 & 37 \\
\hline$r<0.95$ or H\&M validity check & 2 & 10 & 2 & & 12 \\
\hline Successful results & $51^{\mathrm{H \& M}}$ & $44^{\mathrm{HEM}}$ & $51^{\mathrm{H \& M}}$ & $55^{\text {H\&M }}$ & 23 \\
\hline
\end{tabular}

* Overall p-value 0.097, **Overall p-value 0.067, H\&M Significant difference against H\&M method ( $p<0.05$ ) 


\subsection{Methods' degree of agreement with measured data}

We evaluated the degree of agreement of the analytical methods with the measured data by calculating the absolute values of the differences between measured and calculated $\mathrm{F}_{\mathrm{E}} \mathrm{NO}$ values at flow rate $100 \mathrm{ml} / \mathrm{s}$ (Supplementary Table 1). Overall among the linear methods, Condorelli method tended to have a better degree of agreement with observational data than $T \& G$ from which it is derived as it yielded smaller residuals of observed and calculated $\mathrm{F}_{\mathrm{E}} \mathrm{NO}$ values. Pietropaoli method seemed to have a better agreement in every group except the healthy children than other linear methods. Condorelli method had the same degree of agreement as Silkoff in children and COPD patients, whereas Silkoff and T\&G methods gave similar residuals to each other in every group. $H \& M$ and Pietropaoli seemed to have greater degree of agreement with the observational data in all groups except the healthy children. The non-linear methods differed from each other in every group. Overall, H\&M method appeared to have the greatest agreement with observational data.

\subsection{Comparing the magnitude of NO parameters between the methods}

We discovered statistically significant differences among the results of the compared analytical methods (Figures 3-6 and Supplementary tables 2-5). Generally, there were no significant differences between T\&G and Pietropaoli. However as might be expected, Condorelli method with axial back-diffusion correction yielded lower estimates for $\mathrm{C}_{\mathrm{A}} \mathrm{NO}$ and higher estimates for $\mathrm{a}_{\text {aw }} \mathrm{NO}$. Interestingly, Silkoff and Condorelli methods produced similar $\mathrm{C}_{\mathrm{ANO}} \mathrm{estimates}$ with no significant differences in any group. The other linear methods tended to give higher estimates for $\mathrm{C}_{\mathrm{A}} \mathrm{NO}$ and lower estimates for $\mathrm{J}_{\mathrm{aw}} \mathrm{NO}$ as compared to non-linear methods, but the absolute difference was quite small and the differences were not all significant. H\&M and Pietropaoli methods also yielded similar results occasionally. When comparing the non-linear methods to each other, Silkoff method gave higher estimates of $\mathrm{D}_{\mathrm{aw}} \mathrm{NO}$ and lower estimates of $\mathrm{C}_{\mathrm{aw}} \mathrm{NO}$ as compared to $\mathrm{H} \& \mathrm{M}$. There were no consistent differences in $\mathrm{C}_{\mathrm{A}} \mathrm{NO}$ and $\mathrm{J}_{\mathrm{aw}} \mathrm{NO}$ between $\mathrm{H} \& \mathrm{M}$ and Silkoff methods. 

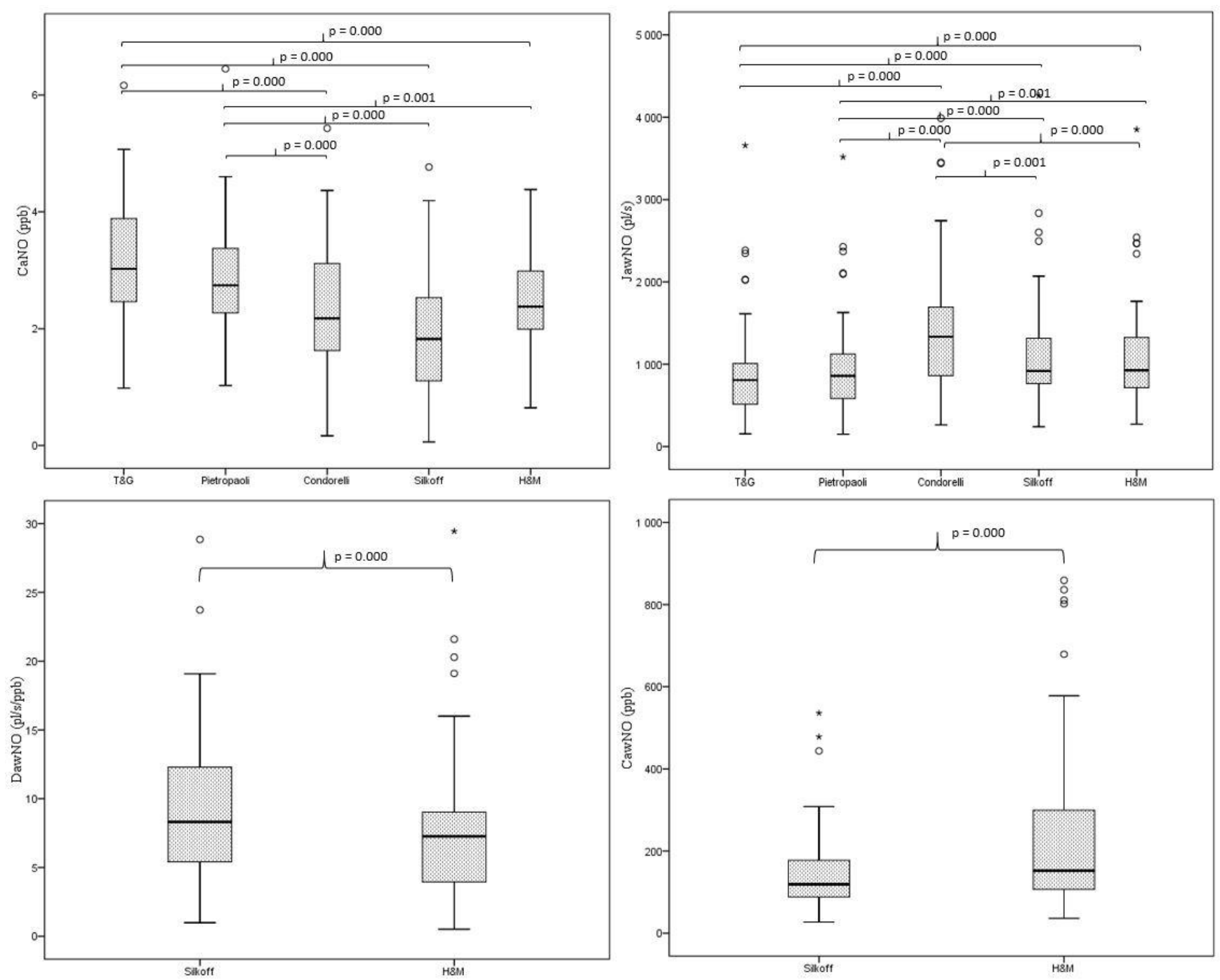

Figure 3. Box plot presentation of the NO parameters of healthy adults using different analytical methods. Only statistically significant differences are marked. 

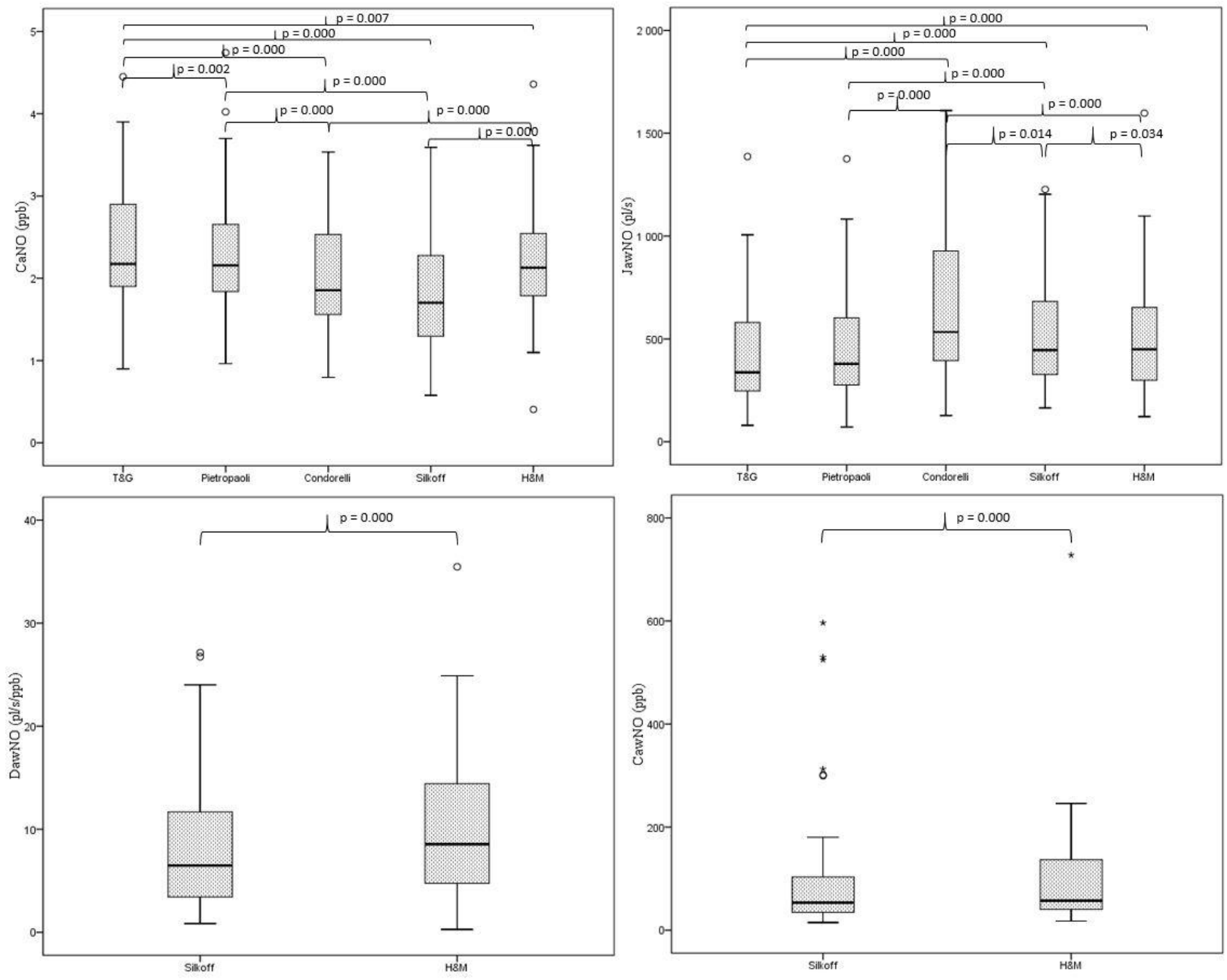

Figure 4. Box plot presentation of the NO parameters of healthy children using different analytical methods. Only statistically significant differences are marked. 

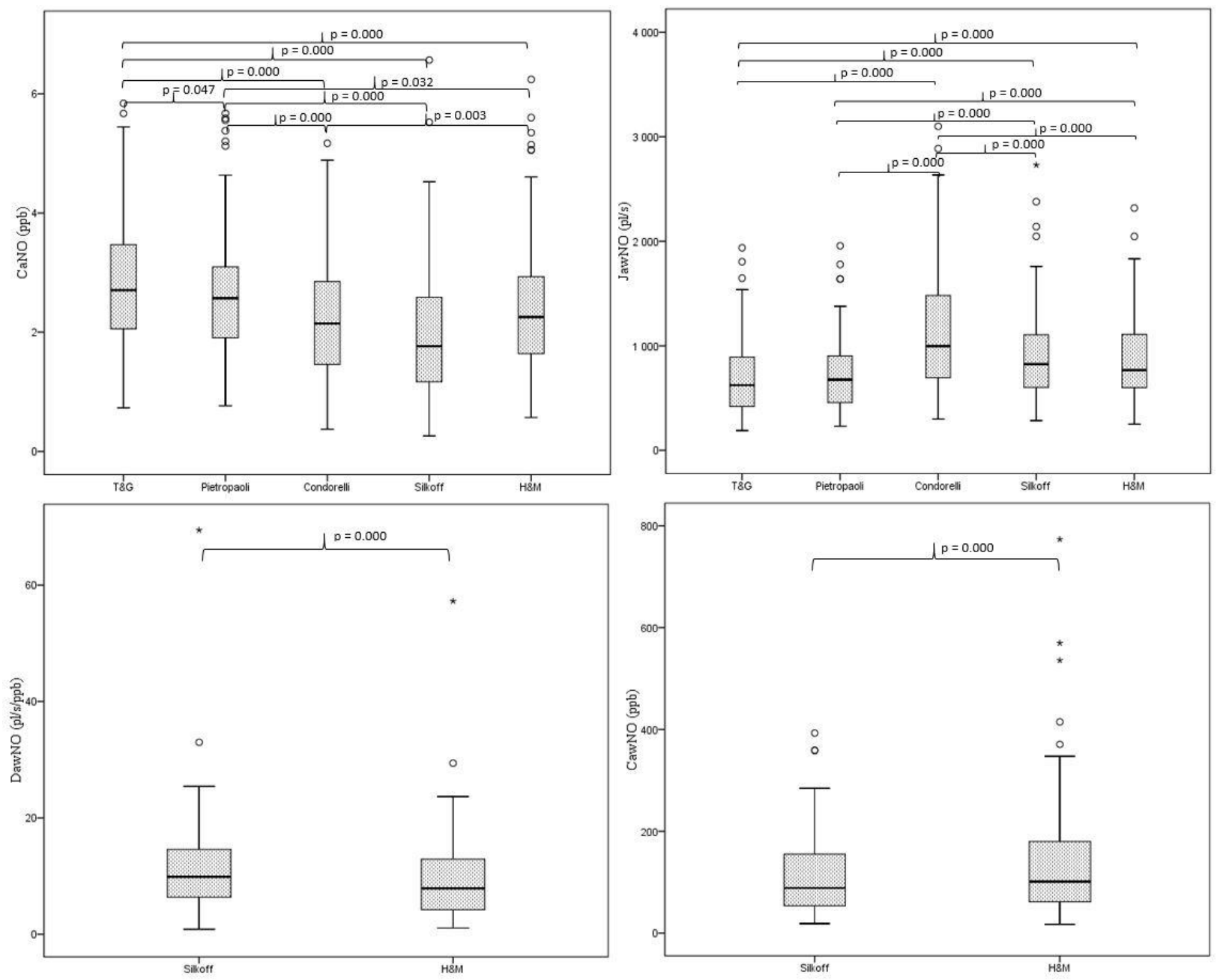

Figure 5. Box plot presentation of the NO parameters of asbestos exposed subjects using different analytical methods. Only statistically significant differences are marked. 

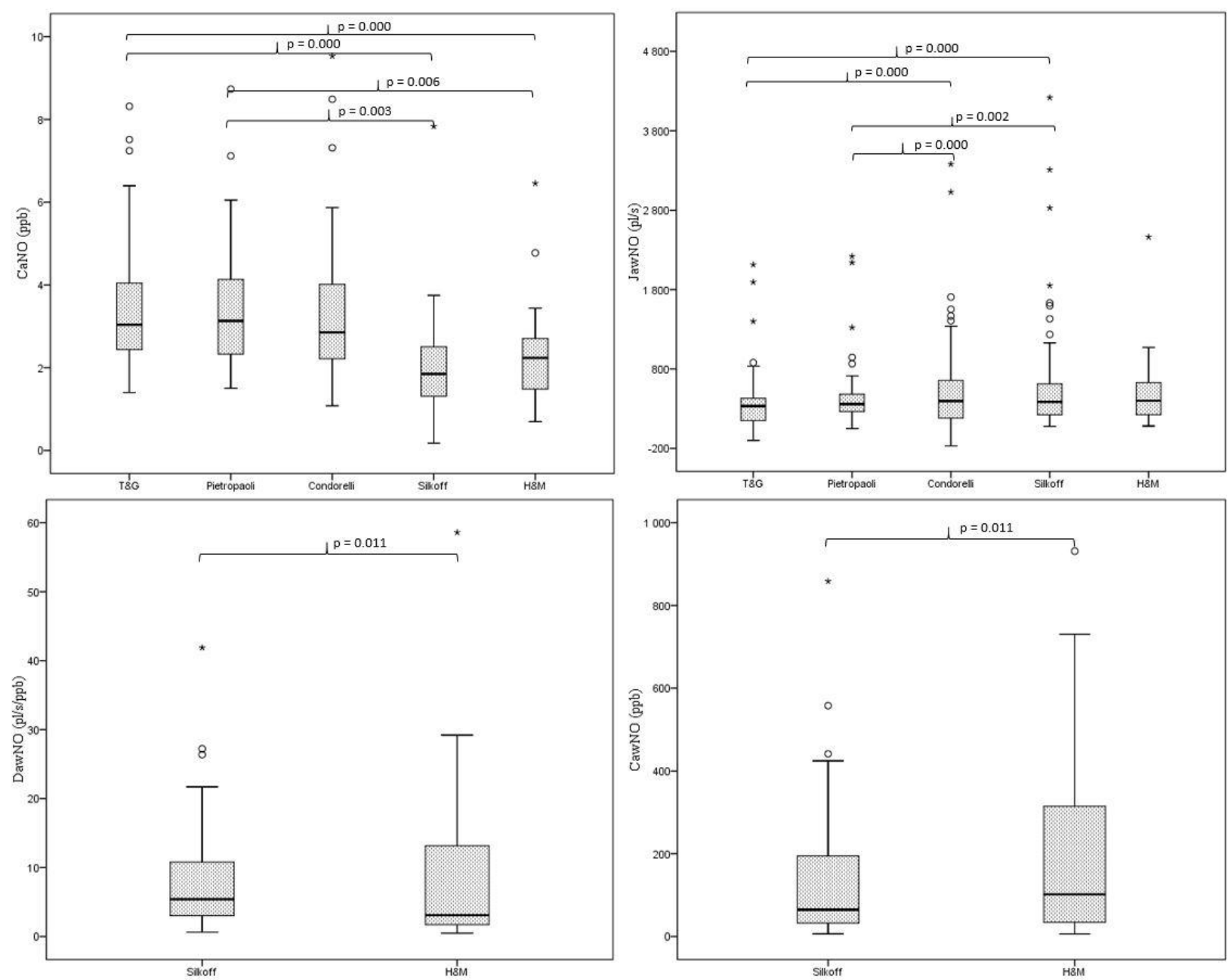

Figure 6. Box plot presentation of the NO parameters of COPD patients using different analytical methods. Only statistically significant differences are marked.

\subsection{Comparing the effect of using different flow rates on feasibility and NO}

\section{parameters}

Different flow rates were compared in healthy adults using $T \& G$ and $H \& M$ (Figures 7 and 8 ) and statistically significant differences were observed in the parameters. In T\&G, there were no differences in feasibility between flow rates, but difference was found between all flow rate combinations in both parameter values. Correlation coefficients had essentially no differences between different flow rate combinations, possibly due to exclusion of all failed measurements.

In the $H \& M$ method flow rates of 20,100,300 ml/s and 20,100, $400 \mathrm{ml} / \mathrm{s}$ differed among every parameter, whereas flow rates of 10,100, $400 \mathrm{ml} / \mathrm{s}$ and $20,100,300 \mathrm{ml} / \mathrm{s}$ were the same among every parameter. Differences in feasibility were found between flow rates 10,100, $400 \mathrm{ml} / \mathrm{s}$ and 20, 100, $400 \mathrm{ml} / \mathrm{s}$ (44 vs 33 
successful results, $p=0.008$ ) and between flow rates $20,100,400 \mathrm{ml} / \mathrm{s}$ and $10,100,300 \mathrm{ml} / \mathrm{s}$ (33 vs 48 successful results, $p=0.000$ ).

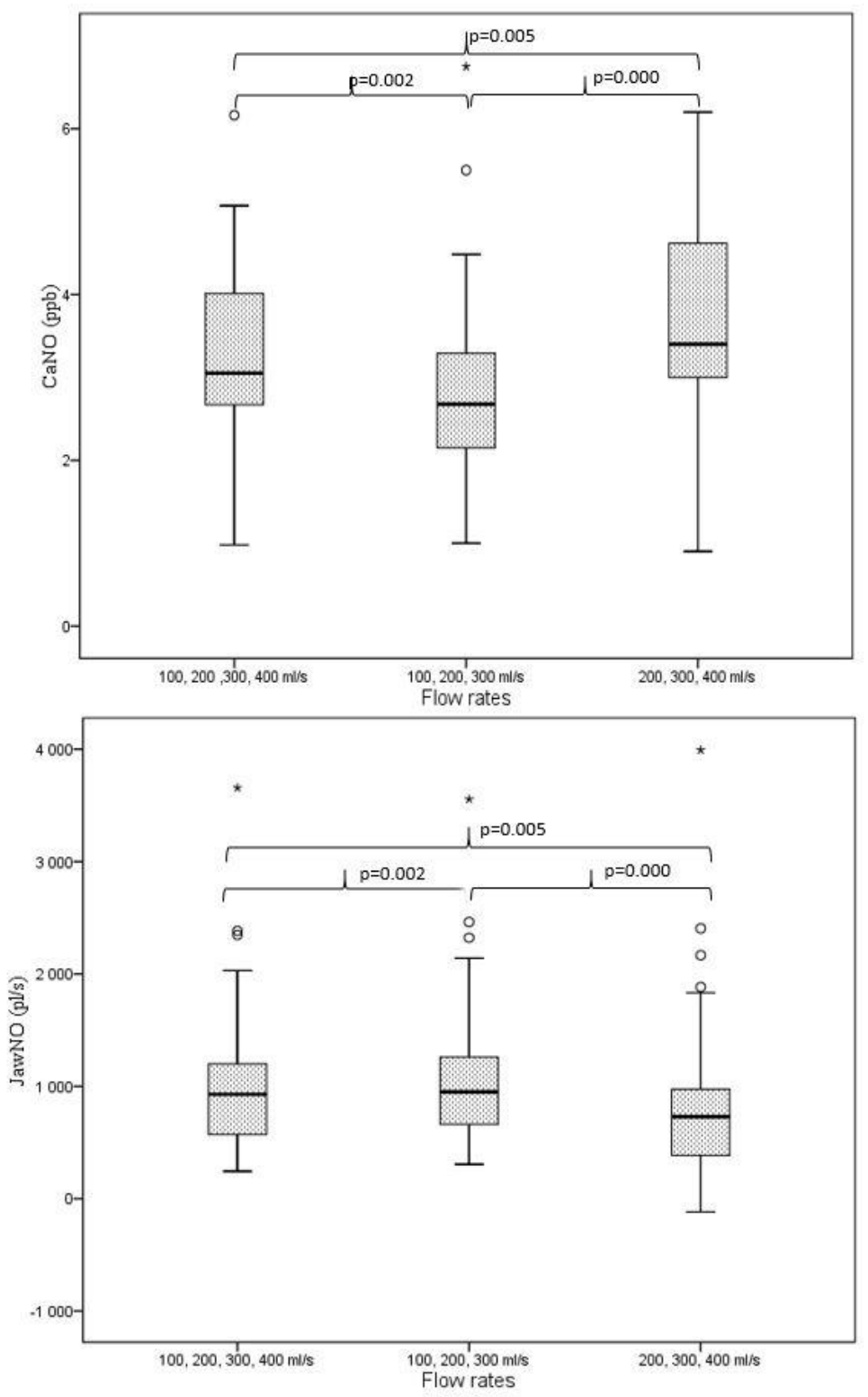

Figure 7. Box plots of the healthy adults' NO parameters using different flow rates in T\&G method. 

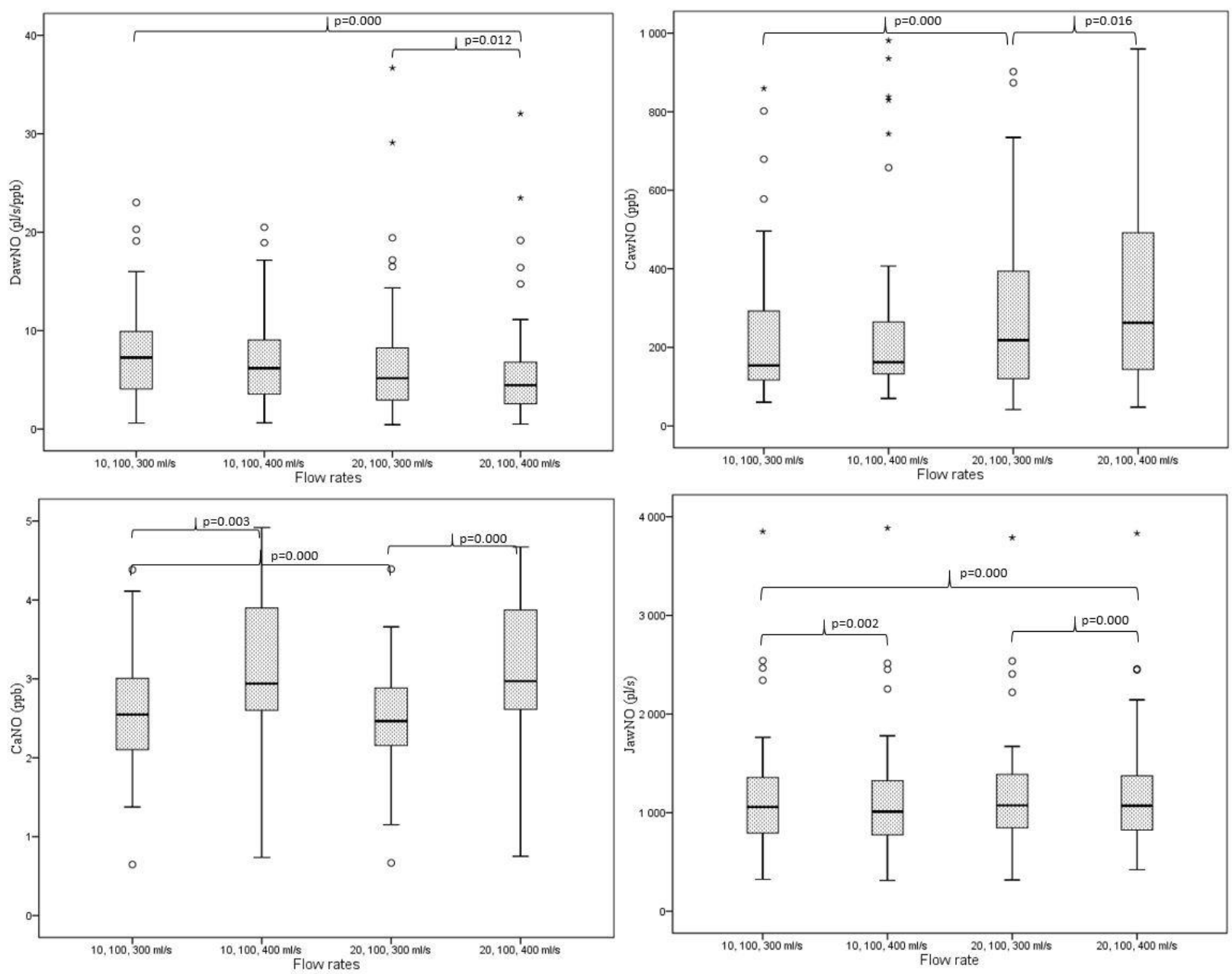

Figure 8. Box plots of the healthy adults' NO parameters using different flow rates in H\&M method. Only statistically significant differences are marked. 


\section{Discussion}

The feasibility of the four methods to calculate NO parameters and their agreement with measured data varied between the methods and between the subject groups. Linear methods and Silkoff method were most frequently feasible, whereas $H \& M$ had the lowest level of feasibility. However, when feasible, $H \& M$ had the highest degree of agreement with the data followed by the linear methods (T\&G, Pietropaoli and Condorelli). The methods were most often feasible in healthy or asbestos-exposed adults but distinctly more infrequently in children and adults with COPD. There were also differences in the calculated NO parameters between the four methods but the two linear methods (T\&G, Pietropaoli) yielded quite similar results as did the two nonlinear methods (H\&M, Silkoff). Condorelli method yielded smaller values for $\mathrm{C}_{\mathrm{A}} \mathrm{NO}$ and larger values for $\mathrm{J}_{\text {aw }} \mathrm{NO}$ than other linear methods, as expected, and the $\mathrm{C}_{A} \mathrm{NO}$ estimates were essentially the same between Silkoff and

Condorlli methods. There is very little previous data comparing these mathematical methods in their feasibility and agreement with measured values.

\subsection{Clinical relevancy and current standardization of multiple flow NO measurements}

$\mathrm{F}_{\mathrm{E}} \mathrm{NO}$ measurement at multiple flow rates has several promising clinical applications. For instance, it has been noticed to be able to detect inflammation in the smaller airways in asthma [24-26]. Peripheral NO production $\left(\mathrm{C}_{\mathrm{A}} \mathrm{NO}\right)$ may also be useful in detecting other inflammatory diseases such as alveolitis and cystic fibrosis $[19,20,26-28]$. Currently, the clinical relevancy of $C_{a w} N O$ and $D_{a w} N O$ is pending. Thus, the clinical importance of non-linear methods over the linear methods is unclear at the moment, although they provide interesting information for research purposes. Potential use for $\mathrm{C}_{\mathrm{aw}} \mathrm{NO}$ and $\mathrm{D}_{\mathrm{aw}} \mathrm{NO}$ might be for example to tell whether elevated $\mathrm{F}_{\mathrm{E}} \mathrm{NO}$ is due to inflammation in the airways or change in airway diffusivity of nitric oxide $[29,30]$. $\mathrm{D}_{\mathrm{aw}} \mathrm{NO}$ and $\mathrm{C}_{\mathrm{aw}} \mathrm{NO}$ might therefore be used in airway diseases as separate measures of tissue remodeling and inflammatory activity, respectively. Clinical relevancy of all the NO parameters is unknown especially in COPD patients, where different pathophysiological aspects of the disease, such as emphysema, may have opposing effects on NO parameters. Also, the parameters should be interpreted cautiously as the current models do not take account the possible effect of obstruction. It has been reported that obstruction may lead to over correction in Condorelli method (lower $\mathrm{C}_{\mathrm{A}} \mathrm{NO}$ and higher aw $_{\text {aw }}$ values are obtained) $[7,8]$.

Currently the predominant problem in $\mathrm{F}_{\mathrm{ENO}}$ measurement at several flow rates is the lack of technical standardization. Different studies have used several different analyzers, setups, flow rates and mathematical methods, making the comparison of the NO parameters between studies challenging. NO parameters are 
known to vary with different used flow rates [31,32] and it is not known whether results obtained using different analyzers yield different estimates for NO-parameters as research has only been done on $\mathrm{F}_{\mathrm{ENO}} \mathrm{N}$ values using single flow rates [33-39]. A recent ERS technical guideline [40] has now for first time given recommendations also on the multiple flow rate NO measurements, but many aspects are still not validated and not standardized. For instance, repeatability of NO parameters, possible circadian variation and differences between distinct $\mathrm{NO}$ analyzers require further research.

\subsection{Feasibility of the methods and their agreement with measured data}

The linear methods were more often feasible (i.e. the mathematical analysis succeeded and provided results that were not considered as outliers) than the non-linear methods. This may be related to more simple mathematics and the avoidance of extremely low flow rates that are difficult to some subjects. The drawback of linear methods is that neither $\mathrm{D}_{\mathrm{aw}} \mathrm{NO}$ nor $\mathrm{C}_{\mathrm{aw}} \mathrm{NO}$ can be estimated. However, these parameters have a minor clinical significance at the moment but may prove to be important when more knowledge on their clinical meaning is gained. The difference between the linear methods was not consistent in feasibility but the Pietropaoli method had on average better agreement with the data.

We found that among the non-linear methods Silkoff method was more often feasible than H\&M method. $H \& M$ method's strength is that only three flow rates are needed, but on the other hand, this makes the method also more vulnerable for measurement errors at any single flow rate. However, $H \& M$ method had the best agreement with our observational data, suggesting that when it is feasible then the quality of data is high and that the better feasibility of the Silkoff method comes with the price of lower agreement with measured data in addition to the need for more flow rates.

Clearly the feasibility of all methods was the poorest in children and especially in subjects with COPD. This is probably related to the subjects' ability to perform reliable $\mathrm{F}_{\mathrm{ENO}} \mathrm{measurements}$ at very low and very high flow rates that usually are the most difficult ones. Molshatski et al. found that high flow rates were most important for estimating $\mathrm{C}_{\mathrm{A}} \mathrm{NO}$, while low flow rates were especially important for estimating $\mathrm{D}_{\text {aw }} \mathrm{NO}$ [31]. This finding may explain the fact that in our study $\mathrm{H} \& \mathrm{M}$ method yielded most relevant results using $10 \mathrm{ml} / \mathrm{s}$ as the lowest flow rate, as recommended by Högman and colleagues $[13,16]$. The extreme flow rates appeared to be problematic especially in the group of COPD patients, explaining the inferior feasibility of linear methods and $H \& M$ method in that group.

Checking for the agreement between the used model and measured data in real-time might help to ensure the quality of the measurements. If the subject was unable to perform very high or low flow rates, Silkoff method seemed to be the most feasible. 
Roy et al. [21] have also compared different mathematical methods and found that $\mathrm{C}_{\mathrm{A}} \mathrm{NO}$ results are significantly model-dependent and median error between calculated and observed data is considerably lower in non-linear methods than mixed methods. Eckel et al. compared nine different mathematical methods in parameter estimation [41]. They suggested using non-linear least squares model with natural log transformation on both sides in parameter estimation. This can be considered as Silkoff method with natural log transformation on both sides. In their study, Pietropaoli method yielded the least number of negative $\mathrm{C}_{\mathrm{A}} \mathrm{NO}$ estimates which is in line with our study where Pietropaoli method yielded least outliers.

On average, the difference between measured and calculated $\mathrm{F}_{\mathrm{E}} \mathrm{NO}$ at $100 \mathrm{ml} / \mathrm{s}$ was very low. The difference would probably be higher at a lower flow of e.g. $50 \mathrm{ml} / \mathrm{s}$ where the relation between $\mathrm{V}_{\mathrm{NO}}$ and $\mathrm{V}_{\mathrm{E}}$ is more nonlinear and the absolute measured ppb values are higher. However, as the linear models do not apply at such low flow rates we decided to use the flow rate of $100 \mathrm{ml} / \mathrm{s}$ in assessing methods' degree of agreement with measured data.

\subsection{Differences in NO parameters between the methods}

There were some statistically significant differences in the NO parameters between the methods but the differences were usually quite small. This is in line with previous reports $[21,41]$. As there is no gold standard to assess the NO parameters it is difficult to say which of the methods yields best estimates.

The linear methods were quite well in line with each other as were the non-linear methods. The linear methods gave higher estimates for $\mathrm{C}_{\mathrm{A}} \mathrm{NO}$ and lower estimates for $\int_{\text {aw }} \mathrm{NO}$ as compared with non-linear methods, but the Condorelli method gave smaller estimates for $\mathrm{C}_{\mathrm{A}} \mathrm{NO}$ and higher for $\mathrm{J}_{\text {aw }} \mathrm{NO}$. This is likely explained by the fact that the linear methods neglect the axial back-diffusion of NO from the conducting region into the alveolar region and our findings support this statement. The fact that the linear approximation of the governing equation of the two-compartment model is only an approximation and the relation between $V_{N O}$ and $V_{E}$ in $T \& G$ method and the relation between $\mathrm{F}_{\mathrm{E}} \mathrm{NO}$ and $1 / \mathrm{V}_{\mathrm{E}}$ in Pietropaoli method is not perfectly linear, may also explain our results as this causes a minor overestimation of $\mathrm{C}_{\mathrm{A}} \mathrm{NO}$ and underestimation of $\mathrm{J}_{\text {aw }} \mathrm{NO}$ [29]. In all subject groups Silkoff method gave similar results with the Condorelli method for $\mathrm{C}_{\mathrm{A}} \mathrm{NO}$. Silkoff method yielded lower estimates for $C_{a w} N O$ and higher estimates for $D_{a w} N O$ as compared to $H \& M$. This probably reflects the difference in the mathematical procedure how these parameters are solved in each of the methods. 


\subsection{Differences in NO parameters obtained using different flow rates}

We found differences in NO parameters obtained using different flow rates. This is in line with previous results that NO parameters vary with different used flow rates [31,32]. We found that the choice of flow rates had more impact on the results of the linear $T \& G$ method than of the non-linear $H \& M$.

\subsection{Strengths and limitations}

Our study has several strengths. We had a relatively large sample size, which provided us with statistical power. All measurements were performed by using the same NO analyzer within same research center, which possibly reduced variation. We had also four distinct subject groups, establishing the comparison of the feasibility of the methods in adults and children and healthy and diseased groups.

However, our study also has weaknesses. Our study included only young children and older adults, lacking young adults. According to previous studies, the flow independent NO parameters vary with age and this may have affected our results [42]. Roy et al. [21]suggested standardizing the number of used flow rates as it significantly affects the NO parameter values. We decided not to standardize our used flow rates as our objective was more to determine whether the parameters can be calculated at all by accommodating the plots if measurement errors were encountered. However, this finding must be taken account as a possible source of error. Another limitation of our study is that we did not have a real-time validity check for the fit between measured $\mathrm{NO}$ data and the mathematical methods but only a check that repeatable $\mathrm{F}_{\mathrm{E}} \mathrm{NO}$ values are obtained at each flow rate. A real-time check of the agreement with mathematical models would probably improve the feasibility of H\&M method especially as it uses only three flows (two flows at a time for each step of the mathematical process) and is vulnerable to measurement errors even at one flow.

\subsection{Conclusion}

In conclusion, if the interest lies in differentiating central and peripheral $\mathrm{NO}$ sources and assessing J aw $_{\text {an }}$ and $\mathrm{C}_{\mathrm{A} O} \mathrm{~N}$, based on the current results we recommend using the linear methods, as low flow rates can be avoided and the feasibility of the methods is good. The difference between Tsoukias \& George and Pietropaoli methods does not seem relevant. However, Condorelli method with correction for axial back-diffusion of NO differed from other linear methods and may not be applicable in subjects with obstruction.

If $\mathrm{C}_{\mathrm{aw}} \mathrm{NO}$ and $\mathrm{D}_{\mathrm{aw}} \mathrm{NO}$ are of interest, we recommend using $\mathrm{H} \& \mathrm{M}$ method as only three flow rates are needed. However, due to its vulnerability, we recommend assessing the agreement between the model and measured data in real-time to ensure the quality of measurements, as the extreme flow rates are observed to be 
problematic to some subjects. If the subject has difficulties with the extremely low or high flow rates, we then recommend using the Silkoff method to improve feasibility. However, more flow rates and FENO measurements are then needed and the agreement between the model and the data may be poorer.

\section{Acknowledgements}

We thank M rs M arja-Leena Lampén, M rs Sari Leinonen, M rs Salla Hietakangas, M rs M arjatta Systä, M rs Kirsti Nilsson and M rs Heli Määttä for assistance. The study was supported by grants from The Finnish Work Environment Fund, Tampere Tuberculosis Foundation, the Finnish Anti-Tuberculosis Association Foundation and the Research Fund of Tampere University Hospital.

We declare no conflicts of interest. 


\section{References}

[1]Lehtimaki L, Csonka P, Makinen E, Isojarvi J, Hovi SL, Ahovuo-Saloranta A. 2016Predictive value of exhaled nitric oxide in the management of asthma: a systematic review. ;48:706-714.

[2]Essat M, Harnan S, Gomersall T, Tappenden P, Wong R, Pavord I, Lawson R, Everard ML. 2016Fractional exhaled nitric oxide for the management of asthma in adults: a systematic review. ;47:751-768.

[3]Petsky HL, Kew KM, Chang AB. 2016Exhaled nitric oxide levels to guide treatment for children with asthma. ;11:CD011439.

[4]Tsoukias NM, George SC. 1998A two-compartment model of pulmonary nitric oxide exchange dynamics. ;85:653-666.

[5]George SC, Hogman M, Permutt S, Silkoff PE. 2004Modeling pulmonary nitric oxide exchange. ;96:831-839.

[6]Condorelli P, Shin H, Aledia AS, Silkoff PE, George SC. 2007A simple technique to characterize proximal and peripheral nitric oxide exchange using constant flow exhalations and an axial diffusion model. ;102:417-425.

[7]Heijkenskjold-Rentzhog C, Nordvall L, Janson C, Borres MP, Alving K, Malinovschi A. 2014Alveolar and exhaled NO in relation to asthma characteristics--effects of correction for axial diffusion. ;69:1102-1111.

[8]Hogman M, Thornadtsson A, Hedenstierna G, Merilainen P. 2014A practical approach to the theoretical models to calculate NO parameters of the respiratory system. ;8:016002.

[9]Heijkenskjold-Rentzhog C, Alving K, Kalm-Stephens P, Lundberg JO, Nordvall L, Malinovschi A. 2012The fraction of $N O$ in exhaled air and estimates of alveolar NO in adolescents with asthma: methodological aspects. ;47:941-949.

[10]Matsumoto H, Niimi A, Jinnai M, Nakaji H, Takeda T, Oguma T, Otsuka K, Inoue H, Yamaguchi M, Matsuoka H, et al. 2011Association of alveolar nitric oxide levels with pulmonary function and its reversibility in stable asthma.;81:311317.

[11]Puckett JL, Taylor RWE, Leu S, Guijon OL, Aledia AS, Galant SP, George SC. 2010An elevated bronchodilator response predicts large airway inflammation in mild asthma. ;45:174-181.

[12]Pietropaoli AP, Perillo IB, Torres A, Perkins PT, Frasier LM, Utell MJ, Frampton MW, Hyde RW. 1999Simultaneous measurement of nitric oxide production by conducting and alveolar airways of humans. ;87:1532-1542.

[13]Hogman M, Drca N, Ehrstedt C, Merilainen P. 2000Exhaled nitric oxide partitioned into alveolar, lower airways and nasal contributions. ;94:985-991.

[14]Tsoukias NM, Tannous Z, Wilson AF, George SC. 1998Single-exhalation profiles of NO and CO2 in humans: effect of dynamically changing flow rate. ;85:642-652.

[15]Silkoff P, Sylvester J, Zamel N, Permutt S. 2000Airway nitric oxide diffusion in asthma - Role in pulmonary function and bronchial responsiveness. ;161:1218-1228.

[16]Hogman M, Holmkvist T, Wegener T, Emtner M, Andersson M, Hedenstrom H, Merilainen P. 2002Extended NO analysis applied to patients with COPD, allergic asthma and allergic rhinitis. ;96:24-30.

[17]Sepponen A, Lehtimaki L, Huhtala H, Kaila M, Kankaanranta H, Moilanen E. 2008Alveolar and bronchial nitric oxide output in healthy children. ;43:1242-1248.

[18]Lehtimaki L, Kankaanranta H, Saarelainen S, Annila I, Aine T, Nieminen R, Moilanen E. 2010Bronchial nitric oxide is related to symptom relief during fluticasone treatment in COPD. ;35:72-78. 
[19]Lehtimaki L, Oksa P, Jarvenpaa R, Vierikko T, Nieminen R, Kankaanranta H, Uitti J, Moilanen E. 2010Pulmonary inflammation in asbestos-exposed subjects with borderline parenchymal changes on HRCT. ;104:1042-1049.

[20]Lehtimaki L, Kankaanranta H, Saarelainen S, Hahtola P, Jarvenpaa R, Koivula T, Turjanmaa V, Moilanen E. 2001Extended exhaled NO measurement differentiates between alveolar and bronchial inflammation. ;163:1557-1561.

[21]Roy K, Borrill ZL, Starkey C, Hazel AL, Morris J, Vestbo J, Singh D. 2007Use of different exhaled nitric oxide multiple flow rate models in COPD. ;29:651-659.

[22]Shin HW, Rose-Gottron CM, Cooper DM, Newcomb RL, George SC. 2004Airway diffusing capacity of nitric oxide and steroid therapy in asthma. ;96:65-75.

[23]Tsoukias NM, Shin HW, Wilson AF, George SC. 2001A single-breath technique with variable flow rate to characterize nitric oxide exchange dynamics in the lungs. ;91:477-487.

[24]Lehtimaki L, Kankaanranta H, Saarelainen S, Turjanmaa V, Moilanen E. 2005Peripheral inflammation in patients with asthmatic symptoms but normal lung function. ;42:605-609.

[25]Lehtimaki L, Kankaanranta H, Saarelainen S, Turjanmaa V, Moilanen E. 2002Increased alveolar nitric oxide concentration in asthmatic patients with nocturnal symptoms. ;20:841-845.

[26]Hogman M. 2012Extended NO analysis in health and disease. ;6:047103-7155/6/4/047103. Epub 2012 Jun 7.

[27]Lehtonen H, Oksa P, Lehtimaki L, Sepponen A, Nieminen R, Kankaanranta H, Saarelainen S, Jarvenpaa R, Uitti J, Moilanen E. 2007Increased alveolar nitric oxide concentration and high levels of leukotriene B(4) and 8-isoprostane in exhaled breath condensate in patients with asbestosis. ;62:602-607.

[28]Sauni R, Oksa P, Lehtimaki L, Toivio P, Palmroos P, Nieminen R, Moilanen E, Uitti J. 2012Increased alveolar nitric oxide and systemic inflammation markers in silica-exposed workers. ;69:256-260.

[29]Hogman M, Lehtimaki L, Dinh-Xuan AT. 2017Utilising exhaled nitric oxide information to enhance diagnosis and therapy of respiratory disease - current evidence for clinical practice and proposals to improve the methodology. ;11:101109.

[30]Hogman M, Merilainen P. 2013Guidance for a personal target value of $F(E) N O$ in allergic asthma: case report and theoretical example. ;118:59-61.

[31]Molshatski N, Eckel SP. 2017Optimal flow rate sampling designs for studies with extended exhaled nitric oxide analysis. ;11:016012.

[32]Chladkova J, Senkerik M, Havlinova Z, Krcmova I, Chladek J. 2012Alveolar concentration and bronchial flux of nitric oxide: two linear modeling methods evaluated in children and adolescents with allergic rhinitis and atopic asthma. ;47:1070-1079.

[33]Kapande KM, McConaghy LA, Douglas I, McKenna S, Hughes JL, McCance DR, Ennis M, Shields MD. 2012Comparative repeatability of two handheld fractional exhaled nitric oxide monitors. ;47:546-550.

[34]Rouhos A, Kainu A, Piirila P, Sarna S, Lindqvist A, Karjalainen J, Sovijarvi AR. 2011Repeatability of exhaled nitric oxide measurements in patients with COPD. ;31:26-31.

[35]Robroeks CM, van Vliet D, Hendriks HJ, Dompeling E, Jobsis Q. 2010Feasibility of exhaled nitric oxide measurements at various flow rates in children with asthma. ;21:e222-8.

[36]Khalili B, Boggs PB, Bahna SL. 2007Reliability of a new hand-held device for the measurement of exhaled nitric oxide. ;62:1171-1174. 
[37]Vahlkvist S, Sinding M, Skamstrup K, Bisgaard H. 2006Daily home measurements of exhaled nitric oxide in asthmatic children during natural birch pollen exposure. ;117:1272-1276.

[38]Buchvald F, Baraldi E, Carraro S, Gaston B, De Jongste J, Pijnenburg MW, Silkoff PE, Bisgaard H. 2005Measurements of exhaled nitric oxide in healthy subjects age 4 to 17 years. ;115:1130-1136.

[39]Kim SH, Moon JY, Kwak HJ, Kim SI, Park DW, Kim JW, Kim TH, Sohn JW, Shin DH, Park SS, et al. 2012Comparison of two exhaled nitric oxide analyzers: the NIOX MINO hand-held electrochemical analyzer and the NOA280i stationary chemiluminescence analyzer. ;17:830-834.

[40]Horváth I, Barnes P J, Loukides S, Sterk P J, Högman M, Olin A, Amann A, Antus B, Baraldi E, Bikova A, et al. 2017A European Respiratory Society technical standard: exhaled biomarkers in lung disease. ;49:https://doi.org/10.1183/13993003.00965-2016.

[41]Eckel SP, Linn WS, Berhane K, Rappaport EB, Salam MT, Zhang Y, Gilliland FD. 2014Estimation of parameters in the two-compartment model for exhaled nitric oxide. ;9:e85471.

[42]Gelb AF, George SC, Camacho F, Fraser C, Flynn Taylor C, Shakkottai S. 2011Increased nitric oxide concentrations in the small airway of older normal subjects. ;139:368-375. 


\section{Supplementary tables}

Supplementary Table 1. Comparison of the methods' degree of agreement with measured data.

\begin{tabular}{|c|c|c|c|c|c|c|c|c|c|c|c|}
\hline & \multicolumn{5}{|c|}{$\begin{array}{l}\text { Absolute values (ppb) of the difference between } \\
\text { measured and calculated } F_{E} N O \text {-values at } 100 \mathrm{ml} / \mathrm{s}\end{array}$} & \multicolumn{6}{|c|}{ p-values } \\
\hline & $T \& G$ & Pietropaoli & Condorelli & Silkoff & $H \& M$ & $\begin{array}{c}\text { Silkoff- } \\
H \& M \\
T \& G- \\
\text { Condorelli }\end{array}$ & $\begin{array}{c}\text { Silkoff- } \\
T \& G \\
\text { Pietropaoli- } \\
\text { Condorelli }\end{array}$ & $\begin{array}{c}\text { Silkoff- } \\
\text { Pietropaoli } \\
\text { Silkoff- } \\
\text { Condorelli }\end{array}$ & $\begin{array}{c}H \& M- \\
T \& G \\
H \& M- \\
\text { Condorelli }\end{array}$ & $\begin{array}{c}H \& M- \\
\text { Pietropaoli }\end{array}$ & $\begin{array}{c}T \& G- \\
\text { Pietropaol }\end{array}$ \\
\hline \multicolumn{12}{|c|}{ Healthy adults } \\
\hline IQR 1. - 3 . & $0,14-0,58$ & $0,03-0,13$ & $0,07-0,28$ & $0,26-1,04$ & $0,01-0,05$ & 0,063 & 0,133 & 0,000 & 0,000 & & \\
\hline Min & 0,00 & 0,00 & 0,00 & 0,02 & 0,00 & & & & & & \\
\hline $\operatorname{Max}$ & 2,02 & 1,39 & 1,21 & 3,52 & 0,75 & & & & & & \\
\hline \multicolumn{12}{|c|}{$\begin{array}{l}\text { Healthy } \\
\text { children }\end{array}$} \\
\hline Median & 0,13 & 0,03 & 0,08 & 0,28 & 0,01 & 0,000 & 1,000 & 0,000 & 0,000 & 0,041 & 0,000 \\
\hline IQR 1. - 3. & $0,07-0,23$ & $0,02-0,06$ & $0,04-0,15$ & $0,09-0,46$ & $0,00-0,02$ & 0,278 & 0,022 & 0,136 & 0,000 & & \\
\hline Min & 0,00 & 0,00 & 0,00 & 0,01 & 0,00 & & & & & & \\
\hline Max & 0,50 & 0,16 & 0,37 & 1,06 & 0,09 & & & & & & \\
\hline \multicolumn{12}{|c|}{$\begin{array}{l}\text { Asbestos } \\
\text { exposure }\end{array}$} \\
\hline Median & 0,24 & 0,06 & 0,17 & 0,46 & 0,02 & 0,000 & 0,941 & 0,000 & 0,000 & 0,243 & 0,000 \\
\hline IQR 1. - 3. & $0,10-0,41$ & $0,02-0,09$ & $0,07-0,28$ & $0,20-0,84$ & $0,01-0,04$ & 0,735 & 0,000 & 0,005 & 0,000 & & \\
\hline Min & 0,02 & 0,00 & 0,00 & 0,02 & 0,00 & & & & & & \\
\hline Max & 0,96 & 0,20 & 0,63 & 5,88 & 0,16 & & & & & & \\
\hline \multicolumn{12}{|l|}{ COPD } \\
\hline Median & 0,18 & 0,03 & 0,44 & 0,37 & 0,00 & 0,000 & 0,219 & 0,000 & 0,044 & 1,000 & 0,336 \\
\hline IQR 1. - 3. & $0,08-0,37$ & $0,01-0,08$ & $0,17-0,84$ & $0,17-0,82$ & $0,01-0,02$ & 0,162 & 0,000 & 1,000 & 0,000 & & \\
\hline Min & 0,00 & 0,00 & 0,01 & 0,03 & 0,00 & & & & & & \\
\hline $\operatorname{Max}$ & 2,25 & 0,44 & 6,81 & 8,36 & 0,06 & & & & & & \\
\hline
\end{tabular}


Supplementary Table 2. Comparison of central and peripheral nitric oxide parameters obtained by using four different mathematical methods in healthy adults.

\begin{tabular}{|c|c|c|c|c|c|c|c|c|c|c|c|}
\hline \multirow[t]{2}{*}{ Healthy Adults } & \multicolumn{5}{|c|}{ Parameter values } & \multicolumn{6}{|c|}{ p-values } \\
\hline & $\mathrm{T} \& \mathrm{G}$ & Pietropaoli & Condorelli & Silkoff & $\mathrm{H} \& \mathrm{M}$ & $\begin{array}{c}\text { Silkoff- } \\
\text { H\&M }\end{array}$ & $\begin{array}{c}\text { Silkoff- } \\
\text { T\&G }\end{array}$ & $\begin{array}{c}\text { Silkoff- } \\
\text { Pietropaoli }\end{array}$ & $\begin{array}{c}\mathrm{H} \& \mathrm{M}- \\
\mathrm{T} \& \mathrm{G}\end{array}$ & $\begin{array}{c}\text { H\&M- } \\
\text { Pietropaoli }\end{array}$ & $\begin{array}{c}\text { T\&G- } \\
\text { Pietropaoli }\end{array}$ \\
\hline & & & & & & $\begin{array}{c}\text { T\&G- } \\
\text { Condorelli }\end{array}$ & $\begin{array}{c}\text { Pietropaoli } \\
- \\
\text { Condorelli }\end{array}$ & $\begin{array}{c}\text { Silkoff- } \\
\text { Condorelli }\end{array}$ & $\begin{array}{c}\text { H\&M- } \\
\text { Condorelli }\end{array}$ & & \\
\hline D $_{\text {aw }} \mathrm{NO}(\mathrm{pl} / \mathrm{s} / \mathbf{p p b})$ & & & & & & 0,000 & & & & & \\
\hline Median & & & & 8,31 & 7,27 & & & & & & \\
\hline IQR 1. - 3. & & & & $5,41-12,29$ & $4,01-9,03$ & & & & & & \\
\hline Min & & & & 0,98 & 0,51 & & & & & & \\
\hline $\operatorname{Max}$ & & & & 28,85 & 29,44 & & & & & & \\
\hline $\mathrm{C}_{\mathrm{aw}} \mathrm{NO}(\mathbf{p p b})$ & & & & & & 0,000 & & & & & \\
\hline Median & & & & 119,10 & 152,15 & & & & & & \\
\hline IQR 1. - 3. & & & & $88,12-177,36$ & $107,26-296,20$ & & & & & & \\
\hline Min & & & & 26,95 & 36,04 & & & & & & \\
\hline $\operatorname{Max}$ & & & & 535,91 & 859,18 & & & & & & \\
\hline $\mathrm{C}_{\mathrm{A}} \mathrm{NO}(\mathbf{p p b})$ & & & & & & 0,077 & 0,000 & 0,000 & 0,000 & 0,001 & 0,196 \\
\hline Median & 3,02 & 2,74 & 2,18 & 1,82 & 2,38 & 0,000 & 0,000 & 1,000 & 0,830 & & \\
\hline IQR 1. - 3. & $2,46-3,88$ & $2,27-3,37$ & $1,64-3,11$ & $1,11-2,53$ & $2,00-2,98$ & & & & & & \\
\hline Min & 0,98 & 1,03 & 0,17 & 0,06 & 0,65 & & & & & & \\
\hline $\operatorname{Max}$ & 6,16 & 6,45 & 5,43 & 4,77 & 4,38 & & & & & & \\
\hline $\mathbf{J}_{\mathrm{aw}} \mathbf{N O}(\mathbf{p l} / \mathbf{s})$ & & & & & & 1,000 & 0,000 & 0,000 & 0,000 & 0,001 & 0,532 \\
\hline Median & 806,67 & 859,08 & 1270,22 & 919,37 & 926,68 & 0,000 & 0,000 & 0,001 & 0,000 & & \\
\hline IQR 1. - 3. & $515,00-1010,00$ & $583,28-1123,69$ & $817,33-1602,67$ & $764,97-1315,98$ & $726,52-1312,12$ & & & & & & \\
\hline Min & 155,56 & 150,00 & 248,89 & 240,63 & 272,85 & & & & & & \\
\hline Max & 3656,67 & 3517,74 & 3813,33 & 4262,83 & 3850,70 & & & & & & \\
\hline
\end{tabular}


Supplementary Table 3. Comparison of central and peripheral nitric oxide parameters obtained by using four different mathematical methods in healthy children.

\begin{tabular}{|c|c|c|c|c|c|c|c|c|c|c|c|}
\hline \multirow[t]{2}{*}{ Healthy children } & \multicolumn{5}{|c|}{ Parameter values } & \multicolumn{6}{|c|}{ p-values } \\
\hline & $\mathrm{T} \& \mathrm{G}$ & Pietropaoli & Condorelli & Silkoff & $\mathrm{H} \& \mathrm{M}$ & $\begin{array}{c}\text { Silkoff- } \\
\text { H\&M }\end{array}$ & $\begin{array}{c}\text { Silkoff- } \\
\text { T\&G }\end{array}$ & $\begin{array}{c}\text { Silkoff- } \\
\text { Pietropaoli }\end{array}$ & $\begin{array}{c}\text { H\&M- } \\
\text { T\&G }\end{array}$ & $\begin{array}{c}\text { H\&M- } \\
\text { Pietropaoli }\end{array}$ & $\begin{array}{c}\text { T\&G- } \\
\text { Pietropaoli }\end{array}$ \\
\hline & & & & & & $\begin{array}{c}\text { T\&G- } \\
\text { Condorelli }\end{array}$ & $\begin{array}{l}\text { Pietropaoli- } \\
\text { Condorelli }\end{array}$ & $\begin{array}{l}\text { Silkoff- } \\
\text { Condorelli }\end{array}$ & $\begin{array}{c}\text { H\&M- } \\
\text { Condorelli }\end{array}$ & & \\
\hline $\mathrm{D}_{\mathrm{aw}} \mathrm{NO}(\mathrm{pl} / \mathrm{s} / \mathrm{ppb})$ & & & & & & 0,000 & & & & & \\
\hline Median & & & & 8,56 & 6,49 & & & & & & \\
\hline IQR 1. - 3. & & & & $4,75-14,42$ & $3,48-11,67$ & & & & & & \\
\hline Min & & & & 0,28 & 0,86 & & & & & & \\
\hline $\operatorname{Max}$ & & & & 35,47 & 27,14 & & & & & & \\
\hline $\mathrm{C}_{\mathrm{aw}} \mathrm{NO}(\mathrm{ppb})$ & & & & & & 0,000 & & & & & \\
\hline Median & & & & 53,60 & 57,28 & & & & & & \\
\hline IQR 1. - 3. & & & & $34,53-103,43$ & $40,83-131,78$ & & & & & & \\
\hline Min & & & & 15,01 & 17,91 & & & & & & \\
\hline $\operatorname{Max}$ & & & & 596,29 & 727,88 & & & & & & \\
\hline $\mathrm{C}_{\mathrm{A}} \mathrm{NO}(\mathbf{p p b})$ & & & & & & 0,000 & 0,000 & 0,000 & 0,007 & 1,000 & 0,002 \\
\hline Median & 2,18 & 2,16 & 1,85 & 1,70 & 2,13 & 0,000 & 0,000 & 1,000 & 0,000 & & \\
\hline IQR 1. - 3. & $1,90-2,89$ & $1,84-2,66$ & $1,56-2,53$ & $1,30-2,28$ & $1,79-2,50$ & & & & & & \\
\hline Min & 0,90 & 0,96 & 0,80 & 0,58 & 0,41 & & & & & & \\
\hline Max & 4,45 & 4,74 & 3,53 & 3,59 & 4,36 & & & & & & \\
\hline $\mathbf{J}_{\mathrm{aw}} \mathbf{N O}(\mathbf{p l} / \mathbf{s})$ & & & & & & 0,034 & 0,000 & 0,000 & 0,000 & 0,532 & 0,278 \\
\hline Median & 336,67 & 378,46 & 533,33 & 445,66 & 449,84 & 0,000 & 0,000 & 0,014 & 0,000 & & \\
\hline IQR 1. - 3. & $246,67-580,00$ & $275,77-602,31$ & $394,67-928,00$ & $326,98-682,70$ & $301,48-651,88$ & & & & & & \\
\hline Min & 80,00 & 71,54 & 128,00 & 164,52 & 122,38 & & & & & & \\
\hline Max & 1386,67 & 1375,38 & 1610,67 & 1227,00 & 1597,65 & & & & & & \\
\hline
\end{tabular}


Supplementary Table 4. Comparison of central and peripheral nitric oxide parameters obtained by using four different methods in subjects with a previous asbestos exposure.

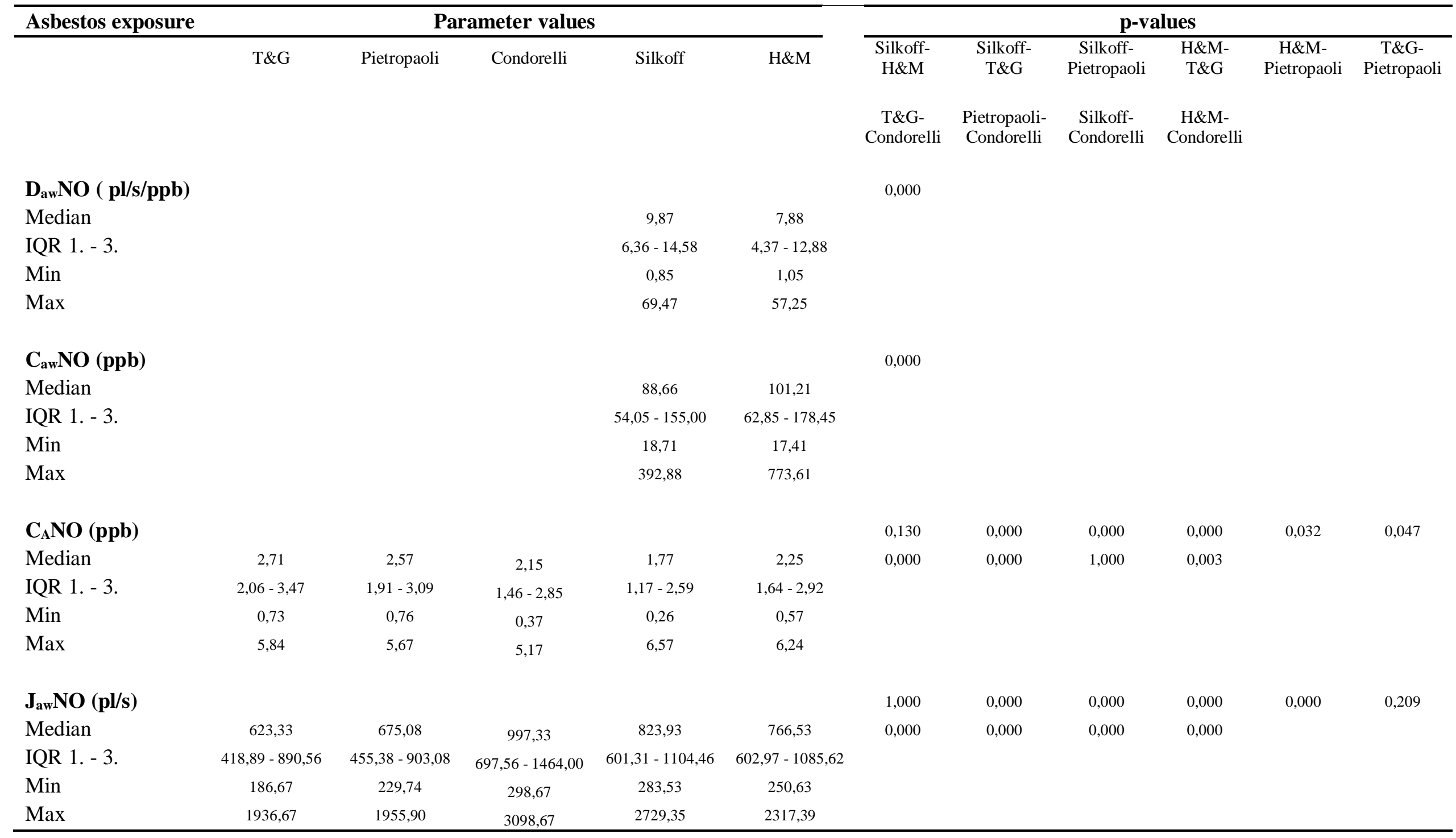


Supplementary Table 5. Comparison of central and peripheral nitric oxide parameters obtained by using four different methods in subjects with COPD.

\begin{tabular}{|c|c|c|c|c|c|c|c|c|c|c|c|}
\hline \multirow[t]{2}{*}{ COPD } & \multicolumn{5}{|c|}{ Parameter values } & \multicolumn{6}{|c|}{ p-values } \\
\hline & $\mathrm{T} \& \mathrm{G}$ & Pietropaoli & Condorelli & Silkoff & $\mathrm{H} \& \mathrm{M}$ & $\begin{array}{c}\text { Silkoff- } \\
\text { H\&M }\end{array}$ & $\begin{array}{l}\text { Silkoff- } \\
\text { T\&G }\end{array}$ & $\begin{array}{c}\text { Silkoff- } \\
\text { Pietropaoli }\end{array}$ & $\begin{array}{c}\text { H\&M- } \\
\text { T\&G }\end{array}$ & $\begin{array}{c}\text { H\&M- } \\
\text { Pietropaoli }\end{array}$ & $\begin{array}{c}\text { T\&G- } \\
\text { Pietropaoli }\end{array}$ \\
\hline & & & & & & $\begin{array}{c}\text { T\&G- } \\
\text { Condorelli }\end{array}$ & $\begin{array}{l}\text { Pietropaoli- } \\
\text { Condorelli }\end{array}$ & $\begin{array}{c}\text { Silkoff- } \\
\text { Condorelli }\end{array}$ & $\begin{array}{c}\text { H\&M- } \\
\text { Condorelli }\end{array}$ & & \\
\hline$D_{\text {aw }} \mathrm{NO}(\mathrm{pl} / \mathrm{s} / \mathrm{ppb})$ & & & & & & 0,011 & & & & & \\
\hline Median & & & & 5,41 & 3,09 & & & & & & \\
\hline IQR 1. - 3. & & & & $3,02-10,77$ & $1,70-13,16$ & & & & & & \\
\hline Min & & & & 0,62 & 0,47 & & & & & & \\
\hline Max & & & & 41,88 & 58,59 & & & & & & \\
\hline $\mathrm{C}_{\mathrm{aw}} \mathrm{NO}(\mathrm{ppb})$ & & & & & & 0,011 & & & & & \\
\hline Median & & & & 64,68 & 101,82 & & & & & & \\
\hline IQR 1. - 3. & & & & $32,22-194,33$ & $34,47-314,42$ & & & & & & \\
\hline Min & & & & 6,36 & 5,95 & & & & & & \\
\hline Max & & & & 858,49 & 931,30 & & & & & & \\
\hline $\mathrm{C}_{\mathrm{A}} \mathrm{NO}(\mathbf{p p b})$ & & & & & & 1,000 & 0,000 & 0,003 & 0,000 & 0,006 & 1,000 \\
\hline Median & 3,04 & 3,20 & 2,85 & 1,85 & 2,23 & 0,162 & 1,000 & 0,139 & 0,253 & & \\
\hline IQR 1. - 3. & $2,39-4,01$ & $2,22-4,00$ & $2,21-4,02$ & $1,31-2,51$ & $1,48-2,71$ & & & & & & \\
\hline Min & 1,40 & 1,50 & 1,08 & 0,18 & 0,70 & & & & & & \\
\hline Max & 8,32 & 8,73 & 9,53 & 7,83 & 6,46 & & & & & & \\
\hline $\mathbf{J}_{\mathrm{aw}} \mathbf{N O}(\mathbf{p l} / \mathbf{s})$ & & & & & & 0,442 & 0,000 & 0,002 & 0,062 & 0,831 & 1,000 \\
\hline Median & 333,33 & 368,46 & 396,67 & 386,21 & 400,42 & 0,000 & 0,000 & 1,000 & 0,139 & & \\
\hline IQR 1. - 3. & $145,56-416,11$ & $266,85-480,92$ & $181,50-656,00$ & $222,54-612,14$ & $224,03-629,95$ & & & & & & \\
\hline Min & $-100,00$ & 46,15 & $-170,00$ & 76,83 & 81,98 & & & & & & \\
\hline Max & 2113,33 & 2220,72 & 3381,33 & 4218,63 & 2462,62 & & & & & & \\
\hline
\end{tabular}

